\title{
THE RETURNS TO SKILL IN THE \\ UNITED STATES ACROSS THE TWENTIETH CENTURY
}

\author{
Claudia Goldin \\ Lawrence F. Katz \\ Working Paper 7126 \\ http://www.nber.org/papers/w7126
NATIONAL BUREAU OF ECONOMIC RESEARCH
1050 Massachusetts Avenue
Cambridge, MA 02138
May 1999

\begin{abstract}
The authors gratefully acknowledge funding from the Spencer Foundation for the collection of the 1915 Iowa State Census and from the National Science Foundation for research support. The authors thank David Autor for his help with some of the reported tabulations from the 1940 to 1990 U.S. federal population censuses. This paper has benefited from presentations at Harvard University, Iowa State University, Boston University, and the Bush Conference Center, Texas A\&M conference on "Increasing Income Inequality in America." The views expressed herein are those of the authors and do not necessarily reflect the views of the National Bureau of Economic Research.
\end{abstract}

( 1999 by Claudia Goldin and Lawrence F. Katz. All rights reserved. Short sections of text, not to exceed two paragraphs, may be quoted without explicit permission provided that full credit, including ${ }^{\odot}$ notice, is given to the source. 
The Returns to Skill in the United States

across the Twentieth Century

Claudia Goldin and Lawrence F. Katz

NBER Working Paper No. 7126

May 1999

JEL No. J2, N3

\section{ABSTRACT}

Economic inequality is higher today than it has been since 1939, as measured by both the wage structure and wealth inequality. But the comparison between 1939 and 1999 is largely made out of necessity; the 1940 U.S. population census was the first to inquire of wage and salary income and education.

We address what the returns to skill were prior to 1940 and piece together the first centurylong history of skill premiums, the dispersion of the wage structure, and returns to formal schooling. We use the 1915 Iowa State Census, a remarkable and unique document, as well as several lessobscure but untapped reports. Using all of these sources, we find that the wage structure narrowed at several moments in the first half of the $20^{\text {th }}$ century, not just in the $1940 \mathrm{~s}$, both coinciding with major economic disruptions brought about by war. The returns to education were in fact higher in 1914 than in 1939, and the enormous expansion in secondary schooling beginning in the 1910 s was a contributing factor to the decrease in educational returns. Inequality and the returns to education across the entire century, therefore, first declined before their more recent and steep ascent.

Claudia Goldin

Department of Economics

Harvard University

Cambridge, MA 02138

and NBER

cgoldin@harvard.edu
Lawrence F. Katz

Department of Economics

Harvard University

Cambridge, MA 02138

and NBER

lkatz@harvard.edu 
Economic inequality in the United States is higher today than at any time in the past sixty years. One would have to return to the period just before our entry into World War II, still during the Great Depression, to find inequality measures comparable in magnitude to those at the current time. Dispersion measures of the wage structure using the 1940 census show that today's is as wide as, or even wider than, that in the United States in 1939 (see the 90-10 log wage differential graph in Figure 1). Current returns to college education are as great as those in 1939 (see the return to college years in Figure 1). Estimates of the percentage of wealth held by the top $1 \%$ or $5 \%$ of the wealth distribution show wealth inequality to be as high at the present time as it was in the late 1930s (Wolff 1995, 1998). We can say less about the distribution of income in 1939 because the 1940 census did not inquire of income from self-employment. ${ }^{1}$ But all other measures of inequality - most having to do with the returns to skill - reveal that 1939 and 1999 look remarkably similar.

Of course, the economy today is not the same as it was sixty years ago. Two differences are most relevant here. Unemployment in 1939 was three to four times its current level and had been persistently high for a decade. Second, real personal income per capita today is about four times what it was in 1939 and the absolute material well being at all points in the income distribution is much higher today than it was sixty years ago. ${ }^{2}$ Both of these differences affect our conception of economic inequality - how we should measure it and why it matters.

In this paper we address what the returns to skill were in the United States prior to 1940 and piece together a full century of skill premiums, the dispersion of the wage structure, and returns to formal schooling. We begin by asking whether the comparison between 1939 and 1999 is a meaningful one since 1939 was an atypical year for the economy and its labor force. After demonstrating that certain

\footnotetext{
${ }^{1}$ Reasonably comparable data on the distribution of family money incomes from the March Current Population Surveys (CPS) are available from 1947 to the present. These data indicate greater inequality of family incomes in the 1990s than in any previous period since 1947 (U.S. Bureau of the Census 1999).

${ }^{2}$ In 1998 the unemployment rate was, on average, 4.5\%. It was $17.2 \%$ in 1939 according to U.S. Bureau of the Census (1975), series D 85, but $11.3 \%$ according to Darby (1976) who nets out individuals in federal works projects. National personal income for 1939 is from U.S. Bureau of the Census (1975), series F 262, and for 1997 is from U.S. Council of Economic Advisers [U.S. CEA] (1998), table B-27. Population figures for both years are from U.S.
} 
distributional measures for 1939 are similar to those for the 1920s, we turn to an examination of the longrun history of distribution in the United States through the lens of the wage structure and the returns to schooling. We are able to accomplish the task because of the recent retrieval of a remarkable and unique document - the 1915 Iowa State Census. We also use several less-obscure materials but ones, nonetheless, that have long remained dormant. Using all of these sources, we find that the wage structure narrowed at several moments in the first half of the $20^{\text {th }}$ century and that the returns to education were in fact higher in 1914 than in 1939.

It may be disconcerting to many that the wage structure today is as wide as it was in 1939, but the wage structure in the early $20^{\text {th }}$ and late $19^{\text {th }}$ centuries was, by our calculations, even wider. We, therefore, return to many of the broader historical issues regarding distribution that deeply divided the nation in the late $19^{\text {th }}$ and early $20^{\text {th }}$ centuries. New programs were adopted across the nation in the form of secondary school expansion and a greater financial commitment of states to public higher education, although it is unclear whether these were deliberately ameliorative. We conclude with a discussion of the meaning of long-run changes in inequality in American history.

\section{Sixty Years of Inequality: 1939 versus 1999}

The comparison between 1939 and the more recent period has been made often for it is, to many, a frightening notion that we may have slid back to a structure of economic rewards similar to that attained near the end of America's greatest depression. But the comparison between 1939 and today is largely made out of necessity and owes little to its potentially interesting chronology.

The 1940 census was the first U.S. federal population census to collect information on annual earnings, weeks worked, and education. Thus the 1940 census, and the year 1939, have been the starting points for most long-term discussions of the wage structure, the income distribution by skill, and the 
returns to education. ${ }^{3}$ The 1940 census, however, is not an uncontroversial document for its measure of income is noisy, it did not request earnings data from self-employment, and its information on education has been shown to overstate attainment at various levels. ${ }^{4}$

The question of relevance here is whether the comparison between 1939 and any later (and more normal) date makes sense. Was 1939 a typical year for the wage structure and the returns to education and skill? After 10 years of record-high unemployment, those at the bottom of the skill distribution might have acceded to extremely low real wages. If so, the wage distribution below the median would have been abnormally and temporarily stretched by 1939. Using this logic, the "great compression" of the 1940s returned the wage structure, by 1949, to its 1929, pre-Depression level. The past two decades would not then be accurately construed as a return to a distant, disturbing, and long-lived period in the history of America's income distribution. Rather, the wage structure of the past two decades would be interpreted, perhaps more frighteningly, as one that has never before been experienced in the United States in a time of national prosperity and low unemployment.

Previous work has established a good case for the opposite conclusion. According to some, the wage structure in 1939 was not simply a product of the Great Depression, but, rather, had been in place throughout the 1920s (Goldin and Margo 1992). The evidence marshaled in support of that conclusion is a set of wages for occupations that are relatively skilled, such as ordinary white-collar jobs (e.g., clerks) and blue-collar craft positions (e.g., machinists). In each case, the ratio of the hourly, weekly, or monthly wage of the more skilled position in the late 1930s to that of a "laborer" at the same time was virtually identical to its level in the late 1920s. The data producing this result came from two separate and consistent series containing no breaks from 1922 to 1952 (one series is for 1923 to 1943).

Considering first the evidence for the white-collar workers, the ratio of the monthly earnings of skilled to unskilled workers did rise during the Great Depression, but then declined toward the end of the

\footnotetext{
${ }^{3}$ See, for example, Autor, Katz, and Krueger (1998) and Murphy and Welch (1993).

${ }^{4}$ On the issue of the overstatement of high school graduation rates in the 1940 census, see Goldin (1998). The overstatement is larger for older cohorts.
} 
1930s. Thus the increase in the ratio during the depths of the Depression was anomalous. Hours per month (or per week) were reduced far more for blue-collar unskilled workers than they were for whitecollar skilled employees in the mid-1930s. But by the late 1930s hours of work resumed their more usual relationship for these two skill groups and the ratio returned to its late 1920s level. The ratio of hourly wages for these two groups, therefore, rose far less during the mid-1930s than did the ratio of their weekly wages. The hourly ratio, too, returned, by 1939 , to its late 1920 s level. There was, in addition, virtually no change in the ratio of either hourly wages or weekly earnings for skilled to unskilled blue-collar workers from the late 1920s to the late 1930s. In sum, the evidence on the wages or earnings of skilled relative to unskilled workers reveals that the levels in the late 1930s were not anomalous by the standards of the preceding decade of the 1920s.

A related, but somewhat different, phenomenon is apparent in the oft-cited income distribution series assembled by Simon Kuznets (1953). The Kuznets data give the proportion of national income earned by the top $1 \%$ or top $5 \%$ of income earners (as calculated from the income tax) from about 1915 to the 1940s. These data show that the income share of the top $1 \%$ or $5 \%$ of earners was smaller in 1939 than it was in the late 1920s. Like almost all other series concerning distribution, such as those regarding wages, earnings, and income, the Kuznets series show a precipitous decline in inequality in the 1940 s. $^{5}$ For example, Goldsmith's (1967, table 1) extensions of Kuznets's estimates indicate that the share of income received by the top 5\% of families (consumer units) declined from $30.0 \%$ in 1929 to $25.8 \%$ in 1939 to $20.9 \%$ in 1947.

The important point here is that the Kuznets series does not rise during the 1930s. Rather, the top portion of the income distribution narrowed during the Great Depression. The Kuznets data, therefore,

\footnotetext{
${ }^{5}$ Goldsmith (1967) and Goldsmith, et al. (1954) revise and extend the Kuznets estimates of the top 1\% and 5\% and also produce quintile measures of the distribution of family personal income. Budd (1967, table 1) reports Gini coefficient summary measures of the family income distribution based on Goldsmith's data indicating a decline from 0.49 in1929 to 0.47 in 1935/36 to 0.44 in 1941. Plotnick, Smolensky, et al. (1998) attempt to derive a $20^{\text {th }}$ century time series of Gini coefficients by extrapolating on the Kuznets income tax data series using information on the relationship between the Gini, the top 5\%, and the unemployment rate for the more recent period. But they add no new material to the Kuznets measures of distribution, and the time series pattern of their estimates of the Gini for
} 
reveal nothing particularly unusual about the late 1930s in comparison with the 1920s.

All evidence to date, therefore, is in agreement that 1939 is not an oddity or an anomaly with respect to the various measures of inequality. It is even possible that the income distribution was more compressed in 1939 than in the 1920s. Because there is considerable evidence that both the wage structure and income inequality at the top in 1939 were not unusual in comparison with the late 1920s, we can ask whether the wage structure was even wider earlier in the century and whether the returns to education were yet higher.

\section{Pre-1940 Trends in the Wage Structure}

\section{Manual Workers: Existing Literature on Skill Premiums}

Considerable effort has been expended to produce estimates of the pre-1940 wage premium to skill for manual workers (e.g., Bell 1951; Keat 1960; Lebergott 1947; Ober 1948; Woytinsky 1953; Williamson and Lindert 1980). The literature was largely motivated by the wage compression of the 1940s and most was written in the immediate post-World War II period, as is apparent from the publication dates. Several of the studies (e.g., Keat, Ober, Woytinsky) measure skill premiums by constructing the ratio of the earnings of skilled production workers in manufacturing to low-skilled workers, such as "laborers," helpers, janitors, and teamsters. Others (e.g., Bell, Lebergott) examine changes in wages by narrowly defined occupations. ${ }^{6}$

Keat (1960) examined two dates, 1903 and 1956, and found that the wage structure narrowed considerably in the intervening half-century. He concluded that much of the narrowing was due to decreased costs of training and education, in part due to the increase in publicly funded formal education.

1929 to 1944 is inconsistent with that of the direct measures reported in Budd (1967).

${ }^{6}$ Bell (1951) creates a distribution of wages by industry where each wage is an average for an occupation. He does this for different years and measures percentage changes at points in the distribution. Oddly enough, Bell gives only his conclusions and no data. Lebergott (1947) had earlier done about the same thing for two years, 1900 and 1940, and looked at the degree to which there was convergence in wages for specific industries. He chose occupations in each industry that did not change significantly during the 1900 to 1940 period. 
Ober (1948) used annual information on skilled and unskilled building tradesmen (union wage scales) from 1907 to 1947, and also a more general set of skilled and unskilled occupations for five dates between 1907 and 1947. In both cases, and also in his related work on the printing trades (Woytinsky 1953), Ober uncovered two periods of persistent narrowing, one in the late 1910s and the other from the late 1930 s to 1947 , the end of his period. Ober emphasized the roles of inflation, changes in "fairness" norms in setting wages at the lower end, and automation in rendering many unskilled jobs superfluous (see also Jerome, 1934 on mechanization). Lebergott (1947) examined wages by occupation for various industries from 1900 to 1940 and found strong evidence of compression. Lebergott's data not only support the notion that there was compression in the wage structure for manual workers prior to the 1940s, but also that the timing of the change was between 1913 and $1931 .^{7}$

The important point is that the literature on the wage structure for the manual trades is in agreement in finding compression in the structure of wages during the 1940s. Most researchers also report a narrowing of the wage structure before 1940, although there is some disagreement on its timing.

\section{Manual Workers: Extensions Regarding the Wage Structure}

We have uncovered new and superior evidence supporting the notion that the wage structure for manual workers compressed sometime between 1890 and 1940. The data give the wage structure for production workers in 1890 and c.1940 in various manufacturing industries matched between the two years. Rather than estimating the ratio of wages for craft workers to those for laborers or for a range of occupations in particular industries, as was done in much of the previous literature, we produce summary statistics for the full distribution of wages for manual workers in manufacturing.

The data for 1890 come from special tabulations of the 1890 Census of Manufactures. The 1890

\footnotetext{
${ }^{7}$ Williamson and Lindert (1980) construct a long-run series similar in spirit to Ober's and, in fact, use Ober's series for the critical 1907 to 1920 period. Although their series shows compression in the 1940s, it does not reveal any persistent narrowing from the late $19^{\text {th }}$ century to the $1940 \mathrm{~s}$. The finding is entirely explained by an error made in copying the Ober 1920 data point, the year of an important splice to the NICB data (see Williamson 1975, table 11). The 1920 Ober data point should have been 166 but was, apparently, mistakenly copied as 186 . When that error is corrected, the series has virtually identical properties to Ober's original series. The series decreases during World War I, recovers somewhat in the early 1920s but never regains its high pre-war level, and then decreases
} 
schedules included a question on the number of employees by weekly wage brackets, but the data were not published in the volumes containing the national data by industry. Instead, the wage distribution data were published in a volume on urban manufacturing (covering the 165 largest cities in 1890) and in the special industry reports.

The data for c.1940 were derived from studies comprising the "wage and hours" series, which have been executed by the Bureau of Labor Statistics ever since the 1890 s. $^{8}$ The series changed form over the years, shifting in 1907 to union wage scales and then in the 1930s to all workers. At some point in the 1930s the surveys began to report the full distribution of weekly or hourly wages by industry. In the years just after passage of the Fair Labor Standards Act (1938), the reports often noted the impact of the minimum wage on the bunching of employment by wages. During and after World War II the surveys occasionally provided information on the impact of war industries, collective bargaining, and extensions of the minimum wage.

In most respects, the comparability between the data for 1890 and c.1940 is fairly good. In both years we can compare the distribution of wages for male workers (older than sixteen years in 1890) in relatively narrow brackets. The one potentially important difference is that data for 1890 refer to weekly wages, whereas those for 1940 are for hourly earnings. Because workers with lower hourly earnings often worked more hours than those with higher hourly earnings, the bias should make the 1890 distribution more, rather than less, compressed in comparison with c. $1940 .{ }^{9}$ We have located twelve reasonably similar industries with data for both years. ${ }^{10}$

again in the 1940s.

${ }^{8}$ The B.L.S. publication Employment and Earnings is the modern version of this series.

${ }^{9}$ On the relationship between earnings and hours worked for the past and present, see Costa (1998). There are two industries in the c.1940 data that have the distribution of weekly, in addition to the hourly, earnings: soap and shipbuilding. For the soap industry, the distribution of weekly earnings is more compressed than that for hourly wages. The reverse occurs for shipbuilding, particularly below the median. But the weekly earnings distribution for shipbuilding in c. 1940 is not as dispersed as it was in 1890.

${ }^{10}$ There are minor differences between the two years in coverage. The 1890 data exclude piece-rate workers whereas those for c. 1940 include them. Men are less affected by this exclusion than would be women in 1890 . The industries having the highest fraction of male production workers paid by the piece in 1890 are furniture and silk. Product lines across the half-century changed in some industries. "Soap and candles" in 1890 becomes soap in c.1940; silk in 1890 becomes "silk and rayon" in c. 1940. The two tobacco industries change their most important 
For most industries in 1890, the wage distributions include both production and non-production workers (e.g., officers, managers, clerical workers), whereas in c.1940 the data include only production workers. We cannot add non-production workers to the c.1940 data, but we can try to subtract them from the 1890 data. To construct a wage distribution for production workers in 1890 , we assume that each non-production worker was paid more than the highest paid production worker. Thus we subtract all nonproduction workers from the top of the wage distribution, an assumption that biases the results toward a narrower distribution of wages in 1890 particularly at the upper end. The extent of the bias will depend on the fraction of non-production workers in the industry, as well as the degree of overlap in the wage distributions of production and non-production workers. The non-production employment shares for 1890 are given in Appendix Table 1 and range from $2.6 \%$ in cotton goods to $40 \%$ in cigars.

Our matched-industry data for 1890 and c.1940 not only has unique evidence on the wage structure, it also represents a large fraction of all male production workers in manufacturing. The twelve industries in the sample had $28 \%$ of all male (time-rate) production workers in manufacturing 1890 and $25 \%$ of all wage earners in manufacturing in $1940 .^{11}$

In almost all cases, see Table 1, the wage structure in our sample was wider in 1890 than in c.1940. This finding is most apparent using the 50/10 measure, but also holds for most of the other summary statistics - 90/50,90/10, and 75/25. The 75/25 and 90/50 statistics change the least with time, and in several industries these measures remain virtually unchanged. One or two even reveal some widening. ${ }^{12}$ But on average, using 1940 employment weights, the distribution narrows for all measures

products between the two years. In 1890 "cigars and cigarettes" is mainly cigars and thus we compare it with cigars in c.1940, while in c. 1940 "chewing, smoking, and snuff" is mainly cigarettes and we compare it with the 1890 category of "chewing, smoking, and snuff" which excludes the less important cigarette category.

${ }^{11}$ For 1890, the source is U.S. Census Office (1895). The hand-trades (e.g., carpentering, plumbing, plastering, blacksmithing) are subtracted from the 1890 total to make it comparable with the later definition of manufacturing. For 1940, see U.S. Bureau of the Census (1942).

12 The "flouring and grist mill products" industry is the one exception across the board, and possibly for good reason since the industry changed radically after 1890. In 1890, there were almost 18,500 flour-mill establishments in the United States. With the diffusion of reduction milling and the invention of methods to grind hard spring wheat, enormous economies of scale resulted (James 1983). Each flour mill, in the earlier era, had just a few high paid workers, whereas after the concentration of the industry, the fraction of less-skilled mill employees increased.

Note that fully $16 \%$ of the male workers in the industry were white-collar workers, many of whom were 
considered. It should be recalled, in addition, that we made various assumptions to exclude white-collar workers from the sample in 1890. These assumptions, by necessity, bias the upper end of the distribution to be more compressed in 1890 than in actuality. Thus it is not surprising that the measures that place more weight on the upper end show the least compression.

The important point made by this review of previous studies and the new evidence on the manufacturing wage structure is that the wage distribution compressed for production workers sometime between 1890 and $1940 .^{13}$ Several factors served to increase the relative supply of educated and skilled workers. Of most importance are the reduction of immigration flows beginning in the late 1910s and the increase in secondary schooling starting in the first decade of the $20^{\text {th }}$ century, a subject to which we will soon return. Another, emphasized in the work of Jerome (1934), relates to compositional changes. Factory electrification of the late 1910s and the 1920s and the installation of hoisting and moving equipment eliminated many low-wage positions, such as "common laborers" and others who hauled goods around the factory floor.

How large was the narrowing in the wage structure of production workers from 1890 to 1940 ? In putting together the story of wage compression in the United States for the full pre-1960s period, it will be useful to consider how the narrowing in the 1890 to 1940 period compares with that of the "great compression" from 1940 to 1950 . Not only do we have evidence on the wage distribution in c.1940, we also have information for nine of the twelve industries for the late 1940s or early 1950s (see Goldin and Margo 1991). On average, the narrowing in the 90-10 log wage difference from 1890 to c.1940 was more

probably owner-operators (see Appendix Table 1). The 90/10 measure in 1890 inclusive of the non-production workers was 2.94 and it exceeds that in c.1940 of 2.69 .

13 The evidence presented in Table 1 concerns changes in the dispersion of wages of male production workers within detailed manufacturing industries. A full analysis of changes in the overall dispersion of production workers in manufacturing requires knowledge of changes in the dispersion of mean industry wages for detailed manufacturing industries. In fact, the available evidence suggests no widening of inter-industry wage dispersion in manufacturing over the period studied. For example, Cullen (1956) finds that inter-industry wage dispersion among 84 manufacturing industries narrowed from 1899 to the mid-1930s, widened in the late 1930s, and narrowed again in the 1940s. Cullen's estimates indicate that overall inter-industry wage dispersion, as measured by the interquartile range, was quite similar in the 1899 to 1904 and 1937 to 1939 periods. Accounting for changes in inter-industry wage dispersion is unlikely to have much effect on our conclusions concerning the substantial compression of the wage distribution for manufacturing production workers from 1890 to 1940 and the further 
than twice as large than it was from c. 1940 to the early 1950s. The weighted average for the change in the 90-10 log wage difference is $27.9 \log$ points for the 1890 to c.1940 period, whereas the weighted average for the c. 1940 to early 1950 s period is $11.6 \log$ points. ${ }^{14}$

\section{Non-Manual Workers: Existing Literature and Extensions}

The literature on the non-manual trades is less abundant than that on the manual occupations. Douglas (1930) presents the earliest series on the wages of "ordinary white-collar workers," by which is meant most clerical employees (e.g., clerks, typists, stenographers, secretaries, bookkeepers) and lowerlevel managers, but not sales workers. In related work, Douglas (1926) used these data to explore the premium to white-collar work and reported a large decrease in the earnings of ordinary white-collar workers relative to manual workers at least since 1900. Douglas's work, unlike that on the wage structure for manual occupations, preceded the wage compression of the 1940s and was motivated, instead, by an interest in the trend in real wages before and just after World War I.

According to Douglas, persons eligible for these white-collar jobs comprised a "non-competing" group before the expansion of secondary schools. But with the "high school movement" of the early 1900s and the vast increase in proprietary commercial schools, the market became flooded with literate and numerate young people who had skills applicable to the commercial workplace. Thus, the decrease in the wage premium to various white-collar positions in the late 1910 s was due to the increase in both formal education and technical training. Douglas also discussed the fact that technical change in the 1900 to 1920 period raised the demand for machinery in the factory, office, and home, and thereby increased the demand for skilled blue-collar workers. This effect, too, served to raise the relative earnings of those in the blue-collar sector.

But various factors complicate Douglas's data and his story of the wage structure. There was,

compression in the 1940s.

${ }^{14}$ The weights are the production-worker share of the industries in 1940. Of the nine industries, two (lumber; tobacco: cigarettes) experienced no compression in the 1940s and one (flouring) may not have for the 1890 to c. 1940 period. For the remaining six that did experience a wage compression in the $90 / 10$ in both periods, the weighted means for the $\log$ differences are $24.7 \log$ points for 1890 to c.1940 and $14.0 \log$ points for c. 1940 to the 
during the years 1900 to 1925 , a substantial increase in the proportion female among ordinary whitecollar workers. In 1890, women were just $20 \%$ of all office workers, but in 1930 , they were $50 \%$ of the group. ${ }^{15}$ There were, as well, large changes in the composition of office jobs. High-ranking secretaries, the keepers of the officers" "secrets," became less numerous and lower-level clerks, typists, and stenographers proliferated. Hand-bookkeepers gave way to machine-operators armed with "comptometers." The Douglas series does not separate the clerical group by sex nor does it present data on separate office occupations. Thus the Douglas series could well overstate the decrease in relative wages due to compositional changes by sex and occupation. Furthermore, the findings Douglas reported could have been transitory. The wage structure among the manual trades in the late 1910s experienced large changes due to the increased relative demand for unskilled workers during World War I and the large wartime inflation. But these effects were generally not maintained through the 1920s. Since Douglas's data do not extend beyond 1926, the question is whether the pre-war premium to ordinary white-collar workers was later reinstated, as it appears to have been for some of the skilled blue-collar trades.

In an earlier work, we constructed several ordinary white-collar earnings series and produced earnings data by sex as well as for detailed occupations (Goldin and Katz 1995). We used virtually all the sources Douglas consulted, added quite a few to the list, and extended the data forward in time to 1940. In Table 2 we report the results from that work, and expand the series yet further in time to 1959 using the public-use micro-data samples for 1940, 1950, and 1960 federal population censuses.

Rather than overturning Douglas's conclusions, the additions from our earlier work served mainly to confirm and extend them. The earnings of ordinary white-collar employees declined relative to those of production workers in manufacturing and the decreases are evident by sex and by occupation. That is, even though clerical occupations became feminized and even though the clerical occupational distribution

early 1950 s.

${ }^{15}$ Goldin and Katz (1995), table 1. Clerical workers are defined here as those in three groups: (1) bookkeepers, cashiers, and accountants; (2) clerks, except those in stores, and (3) stenographers, typists, and secretaries. 
changed, the earnings of each of these groups separately declined relative to those of production workers, by sex, in manufacturing.

Although we are in agreement with Douglas on the broad outlines of the pre-1930 period, some of the details change with our extensions. The decline in the earnings of ordinary white-collar workers relative to manual workers in the Douglas series occurs just after 1900 and the ratio may even have increased from 1890 to 1900 . In our series - for males and females separately - the decline in the relative earnings of ordinary clerical workers occurs in the late 1910s and early 1920s. The resulting lower level then persists to 1939, after which it declines once again. The results are robust to distinctions by sex and by separate occupations, even for tasks that did not experience much change due to technical advances during the period.

The conclusions from our extensions to 1959 serve to place the earlier results in a longer-term perspective. The decrease in the premium to ordinary white-collar work that occurred in the early part of the twentieth century (1895 to 1939) was of a somewhat greater magnitude than that which occurred later (1939 to 1959). Taken together both periods resulted in a decrease in the premium to ordinary whitecollar workers of about $42 \log$ points for female clerical workers and $53 \log$ points for male clerical workers. ${ }^{16}$ The decrease in the premium from 1939 to 1959 was $19 \log$ points for females and $15 \log$ points for males.

There are only a few other white-collar occupations for which data can be compiled from the early 1900 s to the immediate post-1940s period. They include college professors and engineers. ${ }^{17}$

The data on college professors were originally compiled by Boothe (1932) and later extended by Stigler (1956). We have made further extensions, revisions, and robustness checks to the Boothe-Stigler

\footnotetext{
${ }^{16}$ The two series are spliced using the overlap at 1939, assuming that the difference is a factor of proportionately. The estimate for females uses the log of the average wage ratio from 1890 to 1914; that for males uses the log of the average wage ratio from 1895 to 1914.

${ }^{17}$ Earning data also exist for ministers of various Protestant denominations and for public school teachers. The series for ministers also decreases, relative to production workers, before 1940, but the factors causing that decrease are probably be different from those for other white-collar groups since the demand for religious training decreased. The series for teachers is subject to various forces, such as the increased demand for high school instructors in the
} 
series using the original data collected by the U.S. Office of Education. ${ }^{18}$ The findings, given in Table 3, part A, reinforce those in Table 2 concerning ordinary white-collar workers. Relative to production employees in manufacturing, the earnings of college professors were reduced in the late 1910s to early 1920s and the reduction persisted throughout the 1920s and even into the 1930s (see also Figure 2). ${ }^{19}$ The premium to professors then declined again in the 1940s. These findings hold for all ranks of professors.

Full professors around 1910 earned 3.75 times what the average manufacturing employee did. In the 1920s, however, full professors earned less than 3 times that of the manufacturing employee, and in the 1950s they earned slightly in excess of 2 times. Across the half-century from 1910 to 1960, full professors saw their relative earnings cut almost in half. ${ }^{20}$

The series on engineers is the least complete of the group and contains a break in the 1920s. The Bureau of Labor Statistics, in conjunction with several professional societies, surveyed engineers in 1935 on their earnings beginning with 1929. The B.L.S. also conducted a survey in 1946. Prior to 1929, however, the data are retrospective and come from a survey of an engineering society. Several series, therefore, can be produced and are given in Table 3, part B. Although there is a break in the series between 1924 and 1929 and the data from 1904 to 1924 are retrospective, the results are similar to those for the other white-collar series. There is a decrease in the premium from 1904 to the 1920s and then, possibly, another decrease in the 1940s. The relative decline in engineering salaries is less apparent in the data for beginning engineers (cols. 1 and 2) than it is for the "all engineers" series (col. 5).

era of the high school movement.

${ }^{18}$ The Boothe-Stigler data are for land-grant institutions and refer to the 9 to 10 month salaries. See also the notes to Table 3.

${ }^{19}$ Note in Figure 2 that the earnings of professors relative to wage and salary earners in manufacturing rises considerably in the depths of the Great Depression but then resumes its former level. This feature of the series is characteristic of other wage series for skilled relative to unskilled workers.

${ }^{20}$ The ratio of the earnings of full to assistant professors was virtually constant from 1910 to 1960 . We divide the professor earnings by those for all (wage earnings) manufacturing workers. The production worker series, used in the clerical work comparison, does not exist for all years. Note that the manufacturing worker series includes clerical workers in the manufacturing sector. 
Summary on Trends in the Wage Structure: 1890 to 1960

There appears to be convincing evidence that the wage structure compressed in several stages from the late $19^{\text {th }}$ century to the mid- $20^{\text {th }}$ century. Among manual or blue-collar workers, the evidence on the entire wage structure suggests that there was compression in the wage structure sometime between 1890 and 1940. Because various historical wage series on blue-collar workers, such as those from the N.I.C.B. and the I.C.C., do not reveal a decrease in the premium to skilled workers between the early 1920s and 1940, it seems plausible that the decrease pre-dates the early 1920s. ${ }^{21}$ Another compression of the wage structure occurred during the 1940s. Of the two, the first appears to have been twice as large in terms of the 90-10 log wage differential.

There were, as well, two periods of compression for the three white-collar series presented. One occurred sometime before the 1920 s and the other is situated, once again, in the 1940s. Figure 2 presents a summary of the various findings for the white-collar occupations relative to production workers in the manufacturing sector (or all wage and salary earners in manufacturing). With the exception of the increase in the relative earnings of professors during the height of the Great Depression, all series decrease in two giant steps and are level in between. The two periods of compression, moreover, both occurred during war, inflation, and blue-collar union activity.

\section{Returns to Formal Schooling: 1914 to 1995}

The return to years of schooling is another aspect of inequality differences by skill and has generally, though not always, tracked changes in the wage structure. The return to years of college decreased in the 1940s, rose in the 1950s and 1960s, fell in the 1970s, and has, since then, increased substantially (Figure 1). ${ }^{22}$ Because the 1940 federal population census was the first to ask highest grade

\footnotetext{
${ }^{21}$ See Goldin and Margo (1992, table VII) on the Interstate Commerce Commission (I.C.C.) series for skilled and unskilled railroad workers and also for the National Industrial Conference Board (N.I.C.B.) series relating to the hourly pay of skilled and semi-skilled workers in manufacturing relative to unskilled workers in manufacturing.

${ }^{22}$ The decrease in the $1970 \mathrm{~s}$ is one instance in which the returns to college education do not track changes in the wage structure generally.
} 
attained and also the first to inquire of wage and salary income, there have been few estimates of education returns for the period prior to 1940 and none for a large representative sample.

\section{The "High School" Movement: 1910 to 1940}

The returns to formal schooling prior to 1940 is an issue made even more important by the vast increase in education in the first several decades of the twentieth century. In the period from 1910 to 1940, known in the educational history literature as the era of the "high school movement," secondary schools sprouted clear across the nation and youths began to go to high school to learn skills "for life" rather than "for college." Secondary schools in the 1910s and 1920s greatly increased the number of terminal degrees they granted and their graduates immediately took up a host of office and factory jobs. At the start of the high school movement about half of all high school graduates continued with some form of post-secondary school education. But as graduation rates climbed, the fraction of graduates who continued to higher education dropped in half (Goldin 1998). The "masses" entered and graduated from high schools in the early decades of the $20^{\text {th }}$ century as never before, and "mass" secondary school education was unique to the United States at that time. Most European countries did not have mass nonvocational, non-industrial secondary school education that was fully publicly funded until the post-World War II era (Goldin and Katz 1997).

Certain regions of the country led in this "movement." In 1910, the New England states attained the highest secondary school enrollment and graduation rates in the nation. But soon after, the "movement" took root in the Pacific states and those of the West North Central. In those regions, school building and staffing campaigns caused rates of enrollment and graduation to soar and they remained the highest in the nation until the 1950s when the enrollment and graduation rates of all states, even those in the South, began to converge. The increase in the educational stock caused by this rapid increase in the flow of youths into secondary schools was the most important single factor enhancing educational attainment in the United States in the first three-quarters of the $20^{\text {th }}$ century (Goldin 1998). The public and private high school graduation and enrollment rates for the nation as a whole and the West North Central states, a region on which we will focus here, are given in Figure 3. The era of the "high school 
movement" is evident in the figure, especially for the West North Central.

The rapid increase in secondary school enrollment and graduation in the 1910 to 1940 period raises two questions. First, what was the impact of the large increase in the stock of educated Americans and, second, why did the "movement" begin around 1900 to 1910 ? That is, what was the rate of return to high school (and college) around 1910 and how did this return change over the course of the $20^{\text {th }}$ century as cohorts of educated Americans entered the labor force?

\section{The Iowa State Census of 1915}

We have already addressed the question of the return to education to some degree if the premium to ordinary white-collar work is a proxy for the return to secondary school. As Douglas noted, clerical and other office workers, prior to advances in secondary school, formed a "non-competing group." Prior to 1900 the youth who graduated high school most likely came from a family with sufficient means, geographic proximity to a public high school, and foresight. The increase in high school enrollments and graduation served to flood the market with literate and numerate workers whose skills enabled them to move into white-collar office jobs. It also increased the supply of those capable of filling blue-collar positions that required the reading of manuals, deciphering of blue-prints, computing of formulae, and use of elementary science (Goldin and Katz 1998).

Even though the federal census did not ask highest grade completed until 1940, states also took censuses, generally at the mid-point between the federal decennial censuses. Just two states (Iowa and South Dakota) asked a question on educational attainment in their state censuses prior to 1940, and Iowa also asked income from occupation. It is probably not surprising that two states in the West North Central region, a region that led in the high school movement, would also have pioneered in surveying their citizens regarding educational attainment.

There are many fortunate aspects concerning this census. One is that it was taken in 1915 , just on the cusp of the high school movement, and it requested information on income in 1914, just before the large increase in industrial demand due to the Great War. Also fortunate is that the manuscripts from the census survived - on more than 2 million separate index cards - and that they were microfilmed (in 1986) 
by the Genealogical Society of Salt Lake City. Most important is that the census requested detailed information from Iowa's residents concerning educational attainment, current schooling, income, wealth, occupation, unemployment, and church affiliation, to mention a few of the questions. No federal population census - not even the Current Population Survey - has asked the range of questions requested by the 1915 Iowa State Census. That regarding educational attainment, moreover, is exceptionally detailed and reflected the range of educational institutions in which Iowa's residents in 1915 had received instruction. Individuals were asked to give their educational attainment, in years, by type of school: common, grammar, high school, and college.

We have collected a cluster sample of almost 60,000 individuals, about equally divided between Iowa's "large" cities (Davenport, Des Moines, and Dubuque) and ten "rural" counties, where "rural" indicates that the counties did not have a city of more than 25,000 people (see Goldin and Katz 1999b, Appendix). Iowa in 1915 was dotted with tiny towns and villages, and was at the time as "urban" as was the entire United States, if those in incorporated towns and cities constitute the "urban" population. The "rural" sample, therefore, contains both farm and town people. The data set is large and representative and is an approximately 1 in 40 sample of Iowa's 1915 population.

Iowans in 1915 were an exceptionally well educated group compared with others in the United States and had an educational attainment about equal to that of the U.S. population in 1940 (see Table 4). Interestingly, Iowa was twenty-five years ahead of its time in asking a question on educational attainment in its census and was, as well, twenty-five years ahead of its time in the education of its people. In Iowa in 1915 , women 25 to 59 years old, for example, had a mean highest grade completed of 8.86 years (using our version II estimates in Table 4) - exactly the same as that attained by the same age group of women in the entire United States in 1940. Among that same age and sex group, 44.6\% in Iowa had attended some secondary school; in the entire United States in 1940, 46.2\% had. Not only was there a relatively high educational attainment among the adult population of Iowa in 1915, the youth of Iowa attended school to a considerable degree. Although in 1915 most rural areas in Iowa were not served by a local secondary school, $26 \%$ of all 15 to 18 year olds were attending some post-grammar school and $54 \%$ of the age group 
were attending some type of school (Goldin and Katz 1999b, table 4).

\section{Educational Returns by Age and Sector: Iowa 1915}

We present, in Table 5, estimates for the return to years of formal education from a standard ("Mincerian") log annual earnings function augmented to allow the returns to vary for different types of schooling. ${ }^{23}$ Because the 1915 Iowa State Census offers considerable detail regarding education we are able to explicitly separate years of formal schooling by type of school. For males 18 to 65 years old, the return to a year of high school is about 10\%; for the younger group, 18 to 34 years old, the return is about 12\% (Table 5, cols. 1 and 4). Returns to college years are also high and are similarly higher for the younger group, $15 \%$ as opposed to $10 \% .^{24}$ The return to a year of high school or college is about the same in the non-farm occupations as in all occupations.

Perhaps the most surprising result is that the return to a year of post-elementary schooling is substantial for those engaged in farming occupations (Table 5, cols 3 and 6). In a related paper (Goldin and Katz 1999b), we explore this result further and establish that Iowa counties, in both 1915 and 1925, having a greater fraction of adults with post-elementary schooling had higher agricultural productivity. Furthermore, counties with larger increases in the fraction of adults with post-elementary school education had larger increases in agricultural productivity (that is, the 1925-1915 change in education by county is associated with an increase in farm productivity).

Some of the return to years of high school and college was garnered because more education enabled individuals to enter more lucrative occupations in the white-collar sector. The most remunerative non-professional jobs for men in Iowa in 1915 were various sales positions (e.g., travelling salesmen were among the highest paid in the sample). But more education enhanced earnings not just by enabling individuals to shift sectors, from manual to non-manual jobs. The return to a year of high school was

\footnotetext{
${ }^{23}$ By "returns to education" we do not mean the internal rate of return, but, rather, the coefficient on years of education in a ( $\log$ ) earnings regression. That is, the usual assumptions of Mincer's (1974) framework apply - that there are no direct costs of education to the individual and that all persons are in the labor force for the same number of years independent of educational attainment.

${ }^{24}$ Although for reasons of space we do not include the results for women in Table 5, the returns for them were
} 
high even within the white-collar group and it was also high within the blue-collar group. We estimate returns exceeding $8 \%$ per year within either blue-collar or white-collar occupations for males 18 to 34 years old (Goldin and Katz 1999b, table 8).

The role of within and between occupation returns to education can be demonstrated more effectively by adding a full set of occupation dummies to the earnings regressions. ${ }^{25}$ For all males (18 to 65 years old), the addition of one-digit occupation dummies reduces the return to a year of high school from 0.103 to 0.062 . The inclusion of a full set of 3-digit occupation dummies lowers the coefficient to 0.054. Comparable analyses for the blue-collar and white-collar groups separately produce similar results. Thus, for males, the return to years of high school was about equally divided between that due to higher earnings within narrowly defined occupations and that due to a shift to higher paying occupations.

Most importantly, the return to a year of high school (or college) was high in Iowa in 1915. It was considerable even within sectors. Of particular interest in this agricultural state is that the return was substantial within farming. It is no wonder that the high school movement took off at this juncture in U.S. history and that many of the educationally progressive states were agricultural ones such as Iowa. ${ }^{26}$

Given the high relative wages of office workers, it should not be surprising that the return to a year of high school was substantial in 1914. But why was the return also high within the blue-collar sector and within farming occupations? For blue-collar workers a secondary school education provided the cognitive skills that were demanded for entry into the elite craft occupations, such as electrician and machinist. Many of the more educated blue-collar workers in Iowa in 1915 owned shops and garages. More highly-educated farmers read the progressive farming journals, were aware of animal inoculation, could fix various types of machinery, had knowledge of various crop varieties, and knew modern accounting techniques. Iowa's parents in the 1910s spoke of wanting secondary schools in their districts so that their children would not be left behind in the "new world" of business. Even though many of

also high: $10 \%$ for a year of high school and $15 \%$ for a year of college for unmarried women, 18 to 34 years old.

${ }^{25}$ We use the 1940 census occupation codes.

${ }^{26}$ It should also be pointed out that the prairie states and many in the West had among the highest levels of per 
Iowa's educated children would leave the state as adults, and most would leave their home district, secondary school education was valued by the community as a public good (see Goldin and Katz 1999).

Educational Returns in Iowa: 1914, 1939, 1949, and 1959

To make further sense of the value of education in Iowa in 1914 we explore the change in the return to a year of high school and college in 1939, 1949, and 1959 using the IPUMS for 1940, 1950, and $1960 .^{27}$ For comparability across the years we restrict the 1940, 1950, and 1960 samples to full-year, nonfarm, male workers residing in Iowa. ${ }^{28}$ The return to a year of high school or college, or simply to a year of school, declined between 1915 and 1950 (rows 1 and 2 in Table 6) and also between 1915 and 1960 (rows 1 and 3). But there is already substantial evidence that inequality measures, including the return to education, declined between 1940 and 1950. The more important issue is whether the return to a year of secondary schooling or college decreased between 1915 and 1940. The answer to that question will be that it did, but there are several complicating factors that we must first address.

The most important complication is that the 1940 census inquired only of wage and salary income, not income from self-employment, whereas the 1915 Iowa State Census asked for income from one's occupation, which would have included that from self-employment. ${ }^{29}$ The 1950 federal population census, on the other hand, asked for both wage and salary income and that from self-employment given separately. We can, therefore, compare the returns to a year of schooling for wage and salary earners in 1940 and 1950 (also 1960), and then make an adjustment for those with self-employment income in 1940. We do precisely that in producing the adjusted 1940 results given in Table 6, row 7.

In five of the six columns in Table 6 the adjusted figure for 1940 is considerably lower than the estimated return for 1915. Only in the case of college years for the full population are the returns slightly

capita taxable wealth in 1912 and 1922. Iowa was not just a farming state; it was a rich farming state.

${ }^{27}$ The census years are 1940, 1950, and 1960, but the income is for the previous year. In the discussion, we will often use the decennial year for convenience, similarly for the 1915 Iowa State Census.

${ }^{28}$ The 1915 data are restricted to non-farm male workers.

${ }^{29}$ Income from farming was the most important source of self-employment income in the 1915 Iowa data. In comparing the farm income data from the Iowa State census with that on gross agricultural income from the agricultural census, we have concluded that the 1915 Iowa data are, by and large, net income measures 
higher in 1940 than in 1915 and this result may be an oddity. Many in Iowa's older, college-educated population must have attended small denominational liberal arts colleges or bible schools rather than one of the two state institutions or the more modern liberal arts colleges. The return to a year in one of the older-style colleges may not have been as high as in those that appeared later in the $19^{\text {th }}$ century. ${ }^{30}$ It appears, then, that the return to a year of post-elementary education was higher in 1915 than in 1940.

One may wonder whether the decrease in the estimated return to high school and college reflects nothing more than greater selectivity on the basis of ability into the post-elementary grades in 1915 than in 1940 or a decrease in educational performance. The existing literature on sorting by "ability" into secondary and higher education suggests just the opposite. Bishop (1989) cites evidence showing that, from 1917 to 1942, IQ test scores of high school students rose with the large increase in secondary school enrollment. He also demonstrates that the Iowa tests of achievement from 1940 to the early 1960s indicate increased student performance. It does not appear that the innate ability of high school students fell in the inter-war years nor that the quality of secondary schooling fell during and just after World War II. Furthermore, among high school graduates continuing with college others have shown that there was substantially less selectivity, measured by cognitive test scores, in the 1920s than in the 1930s and 1940s (Taubman and Wales 1972). None of these findings should be surprising since, during these periods, both secondary and higher education were becoming more open to rural youths and the children of immigrants in large cities.

A less serious complication concerns unemployment. More education reduces unemployment risk. In normal economic times, the added return to education from this reduced risk of unemployment is minor, but in periods of high unemployment the addition can be large. In 1939 the national unemployment rate was 17\% (Historical Statistics, series D 86). Thus the returns that we report in Table 6 for full year workers in 1940 understate the total returns to education if the reduced risk of

\footnotetext{
${ }^{30}$ See Goldin and Katz (1999a) on the evolution of colleges and universities in the United States. Many of the "older" institutions that had been staffed by two or three faculty were transformed into more modern colleges by expanding in size and having greater specialization in teaching.
} 
unemployment were added.

\section{Educational Returns over the Long Run in the United States}

The data for Iowa on educational returns have value because Iowa was a leading state in the high school movement. But national data are of greater interest. By combining national estimates of returns to schooling from 1939 to 1995 with our case study of Iowa for 1914, we obtain reasonably comparable estimates of returns to a year of high school or college from 1914 to 1995 for the entire nation. We do so by creating two 1914 variants of the national estimates that differ slightly for the high school calculation and not at all for the college calculation. One of the variants (I) uses the change in the Iowa estimates from 1914 to 1939 to construct the national estimate for 1914; the other variant (II) uses the change from 1914 to 1959. The results of these calculations are given in Table 7 and are graphed in Figures 4 and 5.

The justification for our assumption that the change in educational wage differentials in Iowa from 1914 to 1939 is a reasonable proxy for that nationally is as follows. Estimated changes in returns to years of high school and college for Iowa in later periods, such as 1940 to 1960, move closely with national trends. In addition, occupational wage differentials for Iowa from 1914 to 1939 show a pattern of declining white-collar wage differentials similar to, albeit slightly muted than, national estimates such as those depicted in Figure 2. ${ }^{31}$ The higher educational attainment in Iowa than in the nation in 1914 suggests that the estimated decline in educational wage differentials in Iowa from 1914 to 1939 may, if anything, understate the national decline in the educational wage premium.

Returns to a year of high school and college plummeted in the 1940s, as we knew already. But they also fell, or in the case of the returns to college for all men were fairly constant, from 1914 to 1940. The full twentieth century story of the returns to a year of schooling is that they were rather high at the start of the century. With increased educational access, markedly reduced returns were apparent by the 1950s when, despite enhanced access to college, returns increased, although not to the levels achieved before or more recently. As in the findings on the wage structure, the return to schooling around the turn

\footnotetext{
${ }^{31}$ These estimates use the 1915 Iowa State Census sample and the 1940 IPUMS.
} 
of the $20^{\text {th }}$ century was as high, or higher, than it is today. The return to a year of secondary schooling was higher than today and that to college was higher or about the same. The high levels of returns to skill achieved in 1940 were not anomalous; in fact, they were lower than were those twenty-five years before.

\section{Why Inequality Mattered in the Past and Why It Matters Today}

Most agree that regard for the poor, and for those who remain at the bottom of the distribution, accounts for our preoccupation today with inequality. But equity may not be the only reason why inequality matters. High returns to education may signal that capital markets are imperfect. Some have even contended that rising inequality has far-reaching social and political impacts if economic distance produces social distance making political coalitions more difficult to assemble.

But even the most exaggerated allegations today on the impact of rising inequality do not approach those at the close of the $19^{\text {th }}$ century. Few today allege that rising inequality endangers democracy or that a war between the rich and poor is imminent. These were, however, just some of the assertions made a century or more ago by a wide variety of individuals.

Important commentary on the distribution on income and wealth began with the economic downturns of the 1870s and 1880s. Edward Bellamy's overnight best-seller Looking Backward (1888) was an indictment of inequality and presented a vision of a futuristic egalitarian society with benign and efficient socialism. Bellamy's gruesome portrait of the lower classes physically oppressed by capitalists was given real meaning by the events of the following decade. The Homestead (1892) and Pullman (1894) strikes, and the Haymarket (1886) riot that preceded them, were not simply tragic instances of labor unrest and expressions of labor's demands for shorter hours and higher wages. They were important cases in which the military intervened to protect capital. Mounting divisions between labor and capital were codified in Pollock v. Farmers Loan (1895), invalidating the income tax law of 1894. Speaking for the majority, Associate Justice Stephen Field, asserted that the income tax would be the beginning of "a war of the poor against the rich." The decade of the 1890s was one of growing fear of anarchists, later of syndicalists. These were moments of real concern regarding the creation of "classes" 
in America and the growing distance between them. America was beginning to look more like Europe, not just in terms of the distribution of income and wealth, but also in terms of the potential for political upheaval.

The era was also one of third party movements, often a sign of upheaval and discontent. Although neither the Populists nor the Progressives had proposals directly concerned with inequality, their platforms were both motivated by growing differences in economic and political power among economic classes. Progressives were concerned with government corruption, the trusts, and unfair labor practices, and they championed maximum hours laws, worker safety, and the minimum wage.

The timing of social and political expressions of fear of inequality coincides with our finding that the period around the late $19^{\text {th }}$ and early $20^{\text {th }}$ centuries was probably a high point for the wage structure and the return to formal schooling. But we have less evidence regarding income and wealth for this early period. Concern with the social consequences of inequality was most often directed at class divisions and the accumulation of great wealth by the few, rather than the distribution of labor earnings. Yet, Douglas recognized that the increased demand for educated workers during the rise of big business gave those fortunate enough to have received post-elementary schooling a large competitive edge and that such individuals formed a "non-competing group." An ameliorative policy, in the form of the "high school movement," was embraced by thousands of individual school districts in one of the grandest grass-roots movements in U.S. history. Perhaps it was mass secondary school education that checked the more extreme forms of socialism later embraced by Europe.

\section{Some Speculation Concerning Why the Wage Structure Changed}

We have focused in this paper on documenting aspects of the wage structure and the returns to skill in the United States across the twentieth century, but we cannot resist the temptation to speculate on the causes of change. Much research has suggested that long-run change in the distribution of earnings is shaped by a race between the demand for skill, driven largely by industrial shifts and technological advances, and the supply of skill, altered by changes in educational investments, demographics, and 
immigration. $^{32}$

Despite enormous increases in the relative supply of educated workers, the relative earnings of the more-educated today are similar to that which prevailed in the early twentieth century. The share of the work force with at least a high school degree increased five-fold between 1890 and 1940 (Goldin and Katz 1995, table 8) and almost three-fold since 1940 (Autor, Katz, and Krueger 1998, table 1). Even more rapid changes have altered the relative supply of college graduates since the 1940s. Given the facts on relative earnings by skill in the face of the large increase in relative skill supply, there must have been a rapid secular growth in the relative demand for more-skilled workers.

Throughout the $20^{\text {th }}$ century the industrial and occupational distribution of employment shifted in favor of more-educated workers (Autor, Katz, and Krueger 1998; Goldin and Katz 1995; Murphy and Welch 1993). But measured between-industry demand shifts can explain at most two-fifths of overall growth in the relative demand for more-skilled workers. Substantial within-industry demand shifts must also have been a major factor. Skill-biased technological change, therefore, has played an important role in the growing demand for highly educated labor across the $20^{\text {th }}$ century.

Cross-industry patterns of skill upgrading reinforce the notion that skill-biased technological changes, such as the adoption of electric motors in the early twentieth century and computerization in recent decades, have been important. For example, Goldin and Katz (1998) find a strong positive association between changes in the use of purchased electricity and shifts in employment towards moreeducated labor (non-production workers) from 1909 to 1929. Similarly for the more recent period, Berman, Bound and Griliches (1994) and Autor, Katz, and Krueger (1998) find a substantial positive association between skill upgrading and computer investments, employee computer use, and research and development intensity. Increased capital intensity at the industry and plant levels is also associated with greater utilization of more skilled workers throughout the twentieth century. Thus technological change

\footnotetext{
32 The roles of shifts in the demand and supply of skills in wage structure changes from 1890 to 1940, and from 1940 to the 1996, are examined by Goldin and Katz (1995) and Autor, Katz, and Krueger (1998), respectively. See also Juhn (1999), Katz and Murphy (1992), and Murphy and Welch (1992, 1993) for supply-demand analyses of
} 
and capital deepening have both served to increase the demand for more skilled-labor over the long run

The ameliorative role of the supply of skill is illustrated by various episodes of rapid acceleration in the numbers of more educated workers, first with the high school movement in the 1910s to 1920s and later with the labor market entry of the baby boom cohorts in the 1970s. In both periods there were substantial reductions in educational and skill wage differentials. A more difficult issue is the extent to which expansions in the relative supply of educated labor have had long-run effects by altering the skill bias of technological change (Acemoglu 1998) and by changing the work organization to utilize the moreeducated.

An obvious and striking feature of the wage structure changes summarized in Figures 2, 4, and 5 is the timing. The two largest and most persistent periods of wage structure narrowing (the late 1910s and the 1940s) were also ones of world war, inflation, tight labor markets, strong demand for manual workers, rising union strength, and substantial government intervention in the labor market. ${ }^{33}$ Both episodes strongly suggest the importance of labor market institutions and the role of wars in the erosion of customary wage differentials. But many war-time and inflation-related effects on the labor market turn out to be short lived. These, however, appear not to have been. The narrower wage structure possibly engendered by World War I stayed in place throughout the 1920s despite the rapid erosion of union power directly following the war. In contrast, the wages of British white-collar workers relative to those in manual trades, remained at their high pre-World War I until at least the late-1930s (Brown 1977).

A comparison of the American and British experiences can help sort out the roles of market forces from institutional ones. The expansion of secondary schooling began early in the $20^{\text {th }}$ century in the United States, but did not occur in Britain until the late 1940s with the passage of the Education Act of 1944, guaranteeing a publicly financed high school education for all. The timing and speed of the "first compression" in the United States may have been related to the special circumstances of World War

\footnotetext{
U.S. wage structure changes from the 1940s to the 1980 s.

${ }^{33}$ See Goldin and Margo (1992) for a detailed study of the roles of both institutional and supply and demand factors in the narrowing of the U.S. wage structure in the 1940s.
} 
I, but market forces driven by the rapid expansion of high school graduates in the United States kept the narrower structure in place. In Britain, however, the narrowing of the wage structure remained in place only after World War II, although the new Labour government may also have been an important factor independent of educational advances.

Inequality over the Long-Run: Summary of the Evidence from Wages and Returns to Education

In this paper we have extended the data on the wage structure and the returns to education back to the early part of the $20^{\text {th }}$ century and for some series to the late $19^{\text {th }}$ century. We use large, representative samples, one from a newly retrieved set of manuscripts of a state census in 1915 and others from less obscure documents that have somehow eluded investigators. We find, in all of the data we have unearthed, that the wage structure and the returns to education and skill all moved in the direction of greater equality considerably before the better known "Great Compression" of the 1940s. The wage structure narrowed, skill differentials were reduced, and the return to education decreased sometime between 1890 and 1940. Rather than narrowing suddenly in the 1940s, the wage structure underwent several periods of narrowing prior to its celebrated compression in the 1940s. The entire compression of the wage structure across the $20^{\text {th }}$ century, therefore, was larger in magnitude, more drawn out in time, and more complicated in its reasons than has previously been thought. Similarly, the widening of the wage structure and the increase in the returns to education in the post-1970s period, when we have considerably better data, have been shown to be abundantly complex. 


\section{REFERENCES}

Acemoglu, Daron. 1998. "Why Do New Technologies Complement Skills? Directed Technical Change and Wage Inequality,” Quarterly Journal of Economics 113 (November): 1055-89.

American Association of University Professors. various years. Bulletin of the American Association of University Professors (to 1955, continued by AAUP Bulletin). Easton, PA: AAUP.

"Instructional Salaries in 42 Selected Colleges and Universities for the Academic Year 1948-49."

"Instructional Salaries in 41 Selected Colleges and Universities for the Academic Year 1949-50." "Instructional Salaries in 40 Selected Colleges and Universities for the Academic Year 1951-52." "Instructional Salaries in 41 Selected Colleges and Universities for the Academic Year 1953-54." "Instructional Salaries in 41 Selected Colleges and Universities for the Academic Year 1955-56." "Instructional Salaries in 39 Selected Colleges and Universities for the Academic Year 1957-58." "Instructional Salaries in 39 Selected Colleges and Universities for the Academic Year 1959-60."

Autor, David, Lawrence F. Katz, and Alan B. Krueger. 1998. "Computing Inequality: Have Computers Changed the Labor Market?” Quarterly Journal of Economics 113 (November): 1169-1213.

Bell, Philip W. 1951. "Cyclical Variations and Trend in Occupational Wage Differentials in American Industry since 1914," The Review of Economics and Statistics 33 (November): 329-37.

Berman, Eli, John Bound, and Zvi Griliches. 1994. "Changes in the Demand for Skilled Labor within U.S. Manufacturing Industries: Evidence from the Annual Survey of Manufacturing," Quarterly Journal of Economics 109 (May): 367-97.

Bishop, John H. 1989. "Is the Test Score Decline Responsible for the Productivity Growth Decline?" American Economic Review 79 (March): 178-97.

Blank, David M., and George J. Stigler. 1957. The Demand and Supply of Scientific Personnel. New York: National Bureau of Economic Research.

Boothe, Viva. 1932. Salaries and the Cost of Living in Twenty-Seven State Universities and Colleges, 1913-1932. Columbus, OH: The Ohio State University Press.

Brown, Henry Phelps. 1977. The Inequality of Pay. London: Oxford University Press.

Budd, Edward C. 1967. "Introduction." In E.C. Budd, ed., Inequality and Poverty. New York: Norton Press, pp. vii-xxxiv.

Costa, Dora. 1998. “The Unequal Work Day: A Long-Term View.” NBER Working Paper, No. 6419 (February).

Cullen, Donald E. 1956. “The Interindustry Wage Structure, 1899-1950," American Economic Review 46 (June): 353-69.

Darby, Michael R. 1976. "Three-and-a-Half Million U.S. Employees Have Been Mislaid: Or, an Explanation of Unemployment, 1934-1941," Journal of Political Economy 84 (February): 1-16.

Douglas, Paul H. 1926. "What Is Happening to the 'White-Collar-Job' Market?” System: The Magazine of Business. (December). 
Douglas, Paul H. 1930. Real Wages in the United States: 1890 to 1926. Boston: Houghton Mifflin Co.

Goldin, Claudia. 1998. "America Graduation from High School: The Evolution and Spread of Secondary Schooling in the Twentieth Century," Journal of Economic History 58 (June): 345-74.

Goldin, Claudia, and Lawrence F. Katz. 1995. "The Decline of 'Non-Competing Groups': Changes in the Premium to Education, 1890 to 1940.” NBER Working Paper, No. 5202 (August).

Goldin, Claudia and Lawrence F. Katz. 1997. "Why the United States Led in Education: Lessons from Secondary School Expansion, 1910 to 1940.” NBER Working Paper, No. 6144 (August).

Goldin, Claudia and Lawrence F. Katz. 1998. "The Origins of Technology-Skill Complementarity," Quarterly Journal of Economics 113 (August): 693-732.

Goldin, Claudia and Lawrence F. Katz. 1999. "Human Capital and Social Capital: The Rise of Secondary Schooling in America, 1910-1940," Journal of Interdisciplinary History 26 (Spring): 683-723.

Goldin, Claudia and Lawrence F. Katz. 1999a. "The Shaping of Higher Education: The Formative Years in the United States, 1890 to 1940," Journal of Economic Perspectives 13 (Winter): 37-62.

Goldin, Claudia, and Lawrence F. Katz. 1999b. "Education and Income in the Early $20^{\text {th }}$ Century: Evidence from the Prairies, 1915 to 1950," NBER Working Paper (forthcoming). Paper presented at the American Economic Association Meetings, New York City, January 1999.

Goldin, Claudia, and Robert A. Margo. 1991. "Appendix to 'The Great Compression: The Wage Structure in the United States at Mid-Century': Skill Ratios and Wage Distributions: 1920s to 1950s." Xerox. (July).

Goldin, Claudia, and Robert A. Margo. 1992. "The Great Compression: The Wage Structure in the United States at Mid-Century," Quarterly Journal of Economics 107 (February): 1-34.

Goldsmith, Selma. 1967. "Changes in the Size Distribution of Income.” In E. Budd, ed., Inequality and Poverty. New York: Norton Press, pp. 65-79.

Goldsmith, Selma, George Jaszi, Hyman Kaitz, and Maurice Liebenberg. 1954. "Size Distribution of Income since the Mid-Thirties," The Review of Economics and Statistics 36 (February): 1-32.

Historical Statistics. See U.S. Bureau of the Census (1975).

Inter-university Consortium for Political and Social Research [ICPSR]. 1984. Census of Population, 1940 [United States]: Public Use Microdata Sample (ICPSR 8236). Ann Arbor, MI: ICPSR.

James, John. 1983. "Structural Change in American Manufacturing, 1850-1890" Journal of Economic History 43 (June): 433-59.

Jerome, Harry. 1934. Mechanization in Industry. New York: National Bureau of Economic Research.

Juhn, Chinhui. 1999. "Wage Inequality and Demand for Skill: Evidence from Five Decades," Industrial and Labor Relations Review 52 (April): 424-43. 
Katz, Lawrence F., and David H. Autor. 1999. "Changes in the Wage Structure and Earnings Inequality," in O. Ashenfelter and D. Card, eds., Handbook of Labor Economics. Amsterdam: North Holland Press (forthcoming).

Katz, Lawrence F., and Kevin M. Murphy. 1992. "Changes in Relative Wages, 1963-1987: Supply and Demand Factors," Quarterly Journal of Economics 107 (February): 36-78.

Keat, Paul G. 1960. “Long-Run Changes in Occupational Wage Structure, 1900-1956,” Journal of Political Economy 68 (December): 584-600.

Kuznets, Simon. 1953. Shares of Upper Income Groups in Income and Savings. New York: National Bureau of Economic Research.

Lebergott, Stanley. 1947. "Wage Structures," The Review of Economic Statistics 29 (November): 274-85.

Mincer, Jacob. 1974. Schooling, Experience, and Earnings. New York: Columbia University Press for the National Bureau of Economic Research.

Murphy, Kevin M., and Finis Welch. 1992. "The Structure of Wages," Quarterly Journal of Economics 107 (February): 285-326.

Murphy, Kevin M., and Finis Welch. 1993. "Occupational Change and the Demand for Skill, 19401990," American Economic Review, Papers \& Proceedings 83 (May): 122-26.

Ober, Harry. 1948. “Occupational Wage Differentials, 1907-1947,” Monthly Labor Review (August): $27-$ 134.

Plotnick, Robert D., Eugene Smolensky, Eirik Evenhouse, and Siobham Reilly. 1998. "The Twentieth Century Record of Inequality and Poverty in he United States." University of California, Berkeley. Institute for Research on Poverty Discussion Paper 1166-98. (July).

Stigler, George J. 1950. Employment and Compensation in Education. Occasional paper no. 33. New York: National Bureau of Economic Research.

Stigler, George J. 1956. Trends in Employment in the Service Industries. Princeton: Princeton University Press for the National Bureau of Economic Research.

Taubman, Paul, and Terence Wales. 1972. Mental Ability and Higher Educational Attainment in the $20^{\text {th }}$ Century. NBER Occasional Paper 118. New York: National Bureau of Economic Research.

U.S. Bureau of the Census. 1942. Sixteenth Census of the United States: 1940. Manufactures 1939. Vol. I. Statistics by Subject. Washington, D.C., G.P.O.

U.S. Bureau of the Census. 1975. Historical Statistics of the United States from Colonial Times to 1970. Washington, D.C.: U.S. GPO. [referred to as Historical Statistics in the text]

U.S. Bureau of the Census. 1999. Historical Income Tables. http://www.census.gov/hhes/income

U.S. Bureau of Education. various years. Statistics of State Universities and Other Institutions of Higher Education Partially Supported by the State. Bulletins 1908 no. 8; 1909 no. 11; 1910 no. 6; 1911 no. 19; 1913 no. 60. Washington, D.C.: U.S. G.P.O. 
U.S. Bureau of Labor Statistics. various issues. Monthly Labor Review.

"Earnings and Hours of Labor in Private Shipyards, 1936 and 1937," (September 1938).

"Hourly Earnings in Furniture Manufacturing October 1937," (November 1938).

“Average Hourly Earnings in Cotton-Goods Industry, 1937," (April 1938).

"Earnings and Hours in the Soap Industry, January 1938," (June 1938).

"Hourly Earnings in Dyeing and Finishing of Cotton, Rayon, and Silk," (January 1940).

"Earnings and Hours in the Iron and Steel Industry, April 1938," (August 1940).

"Earnings in Gray-Iron and Malleable-Iron Foundries, 1938-39," (November 1940).

"Hourly Earnings in the Lumber and Timber Products Industry," (July 1941).

"Earnings and Hours in the Rayon and Silk Industry, 1940," (August 1941).

"Hours and Earnings in the Cigar Industry, 1940," (December 1941).

"Earnings and Hours in Manufacture of Cigarettes, Chewing and Smoking Tobacco, and Snuff, December 1940," (January 1942).

"Earnings in the Grain-Mill Products Industries, 1941," (April 1942).

U.S. Census Office. 1895. Report on Manufacturing Industries in the United States at the Eleventh Census: 1890. Part I. Totals for States and Industries. Washington, D.C.: G.P.O.

U.S. Census Office. 1895a. Report on Manufacturing Industries in the United States at the Eleventh Census: 1890. Part II. Statistics of Cities. Washington, D.C.: G.P.O.

U.S. Census Office. 1895b. Report on Manufacturing Industries in the United States at the Eleventh Census: 1890. Part III. Selected Industries. Washington, D.C.: G.P.O.

U.S. Council of Economic Advisers. 1998. Economic Report of the President. Washington, D.C.: U.S. G.P.O.

Williamson, Jeffrey G. 1975. "The Relative Costs of American Men, Skills, and Machines: A Long View. Institute for Research on Poverty Discussion Paper 289-75. University of Wisconsin, Madison.

Williamson, Jeffrey G. and Peter H. Lindert. 1980. American Inequality: A Macroeconomic History. New York: Academic Press.

Wolff, Edward N. 1998. "Recent Trends in the Size Distribution of Household Wealth," Journal of Economic Perspectives 12 (Summer): 131-50.

Wolff, Edward N. 1995. Top Heavy: A Study of the Increasing Inequality of Wealth in America. New York: The Twentieth Century Fund Press.

Woytinsky, W.S. (and associates). 1953. Employment and Wages in the United States. New York: the Twentieth Century Fund. 
Figure 1: The Wage Structure and Returns to Education, 1939 to 1995

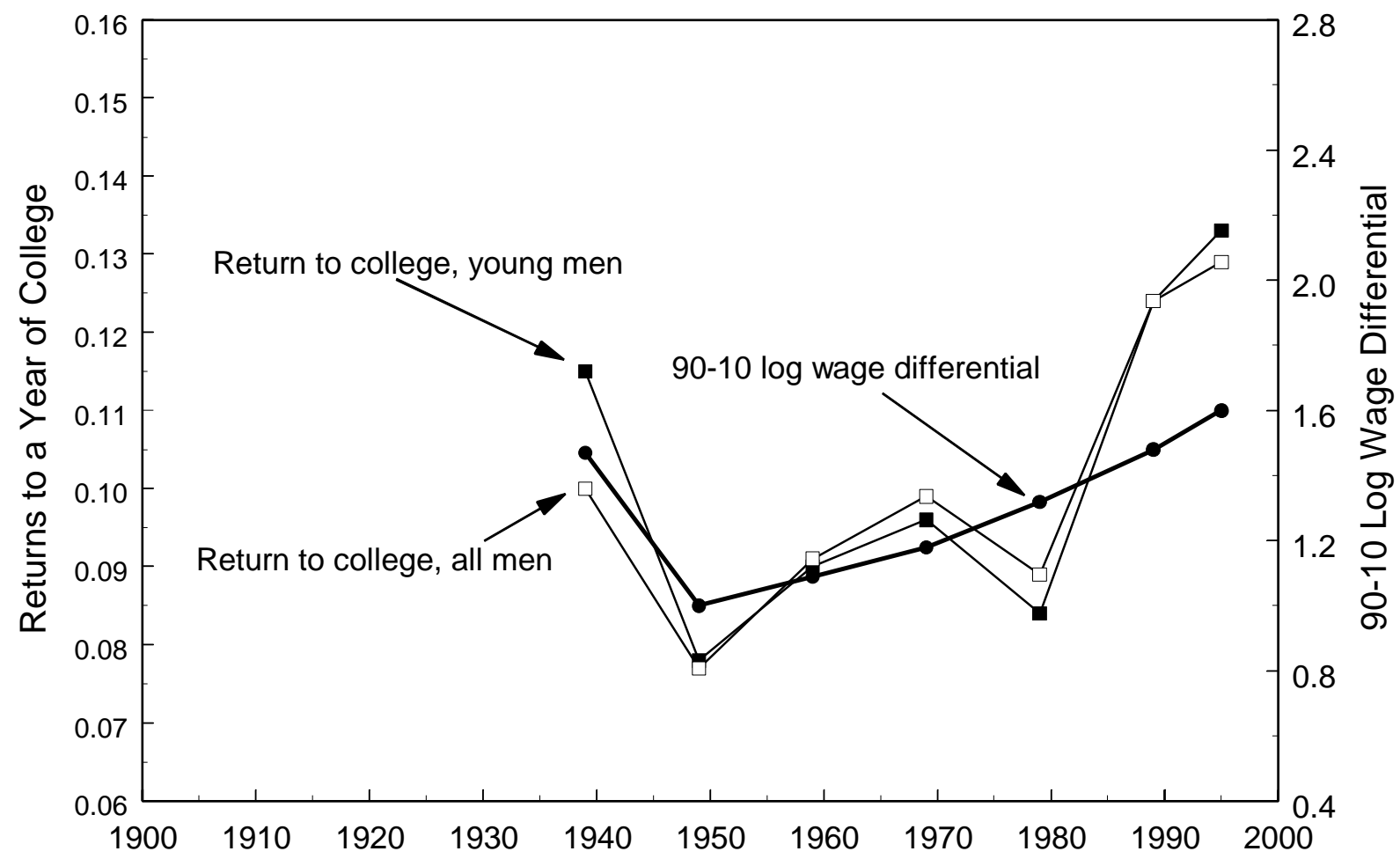

Source and Notes:

90-10 log wage differential: 1940 to 1990 IPUMS, and 1990 and 1996 March CPS from Katz and Autor (1999, forthcoming, table 8 and figure 4), uses weekly wages for full time, full year, non-agricultural male wage and salary workers, 19 to 65 years old. Full time, full year workers are those working 35 hours or more per week and working at least 40 weeks in the previous calendar year.

Return to college: 1940 to 1990 IPUMS, and 1990 and 1996 March CPS. "Young" means 0 to19 years of potential work experience. "All" means 0 to 39 years of potential work experience. The estimates are derived from (composition-adjusted) mean log weekly wages of full time, full year, non-agricultural (white) males with exactly 12 years of schooling and exactly 16 years of schooling in four experience groups (0-9, 10-19, 20-29 and 30-39 years of potential experience). The composition adjustments account for changes in the distribution of years of experience and the regional distribution of employment within each of the 8 education-experience groups. The returns to a year of college for each experience group equals the difference in (composition-adjusted) mean log wages for those with exactly 16 and exactly 12 years of schooling divided by 4 . The estimates of returns to college for "young" and "all" men are weighted averages of the returns for the relevant experience groups using a fixed set of weights (the 1980 share of total hours worked for each experience group). See Katz and Autor (1999, forthcoming) for details. 
Figure 2: Ratios of White-Collar to Blue-Collar Earnings



Sources: See Tables 2 and 3. 
Figure 3: High School Enrollment and Graduate Rates, United States and West North Central

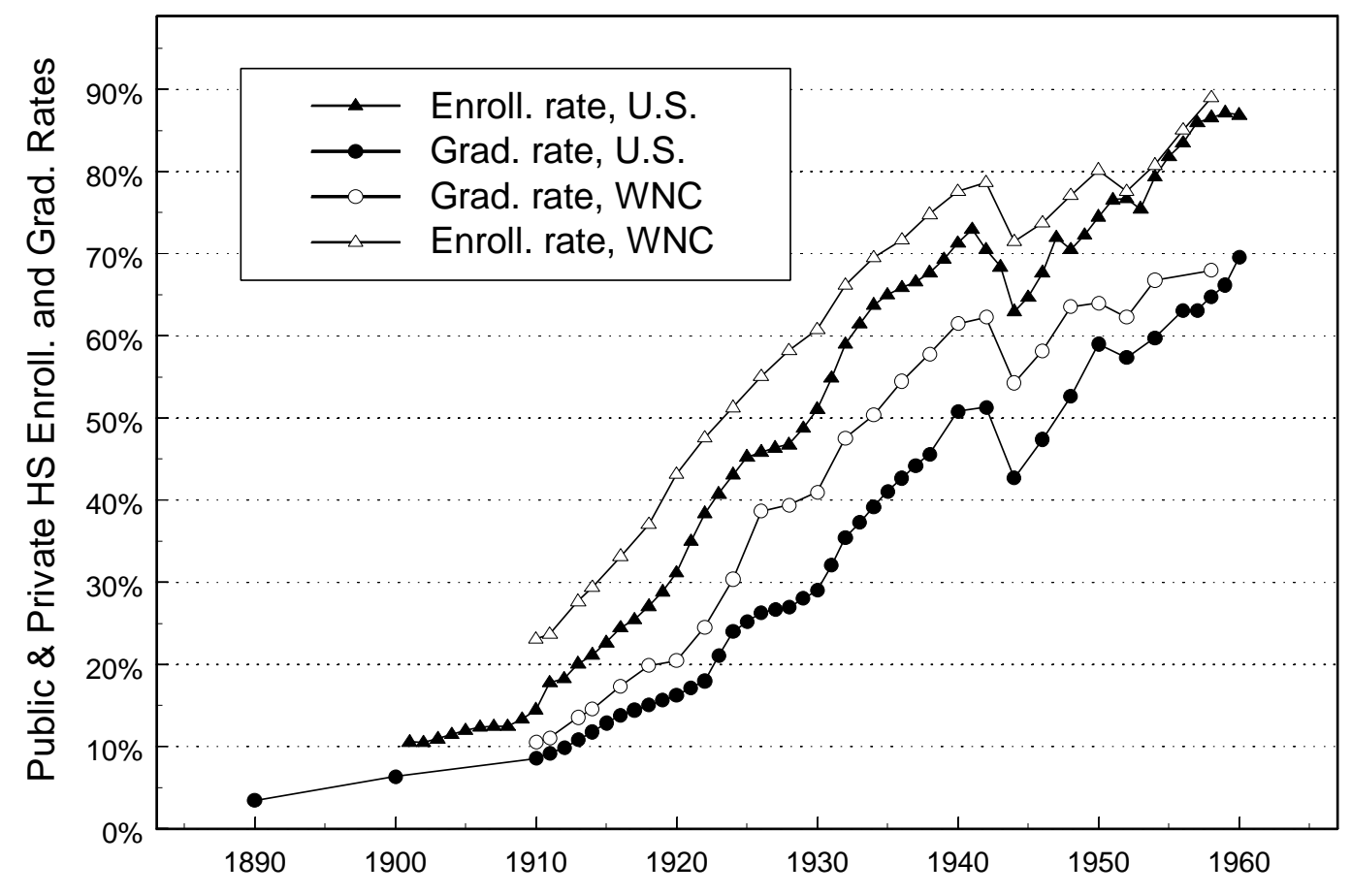

Source: U.S. Department of Education (1993); Goldin (1998).

Notes: The public and private graduation rate is the number of individuals graduating from public and private secondary schools, and the preparatory departments of colleges and universities, divided by the number of 17-year olds. The public and private enrollment rate is the number of individuals enrolled in public and private secondary schools (grades nine through twelve), and the preparatory departments of colleges and universities, divided by the number of youths between 14 and 17 years old. The West North Central census division includes the states of Iowa, Kansas, Minnesota, Missouri, Nebraska, North Dakota, and South Dakota. 
Figure 4: Returns to High School, 1914 to 1995

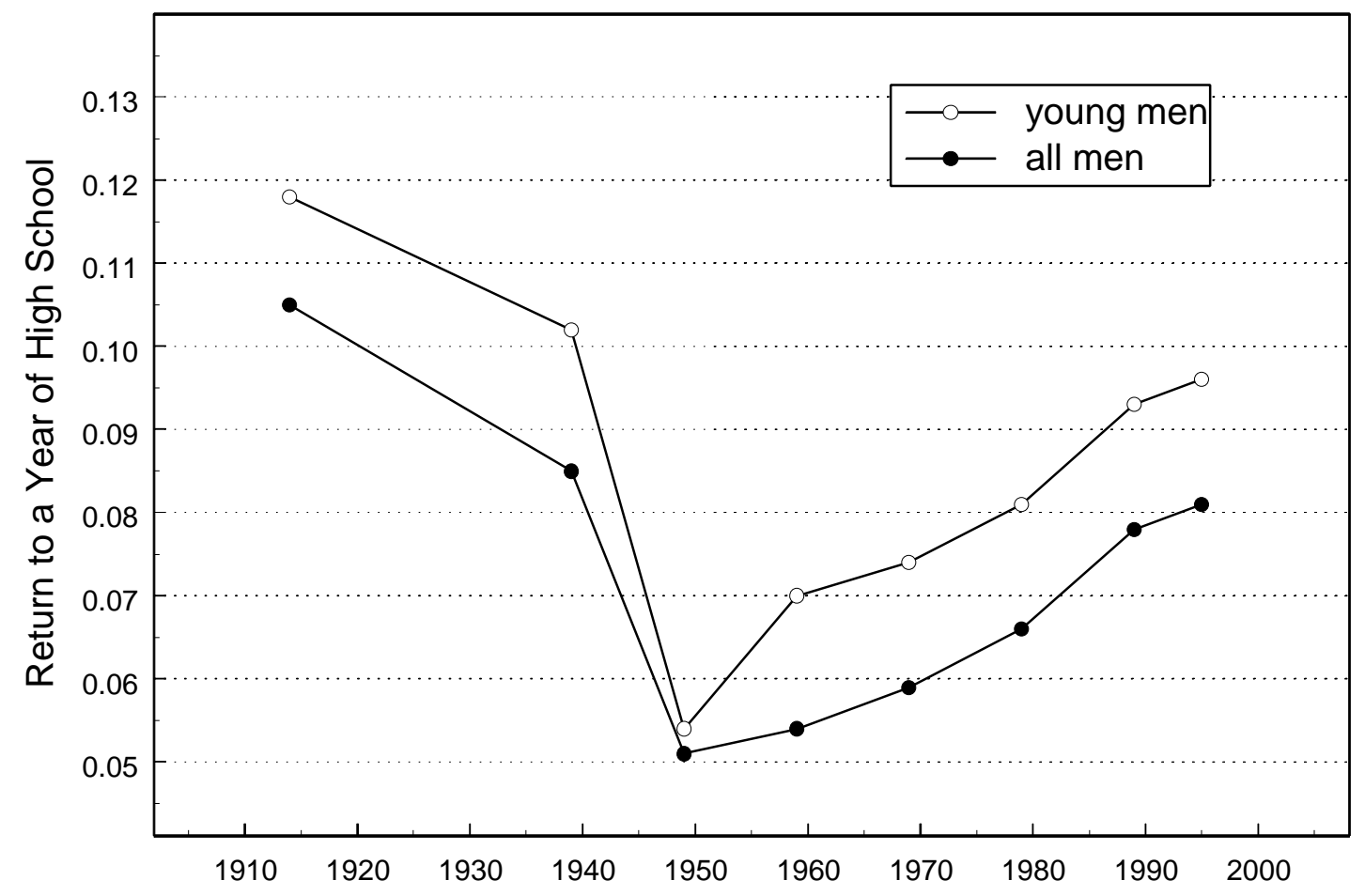

Source and Notes: See Table 7. The 1914 estimate for each group is the average of the corresponding 1914 variant I and variant II estimates of the returns to high school reported in Table 7. 
Figure 5: Returns to College, 1914 to 1995

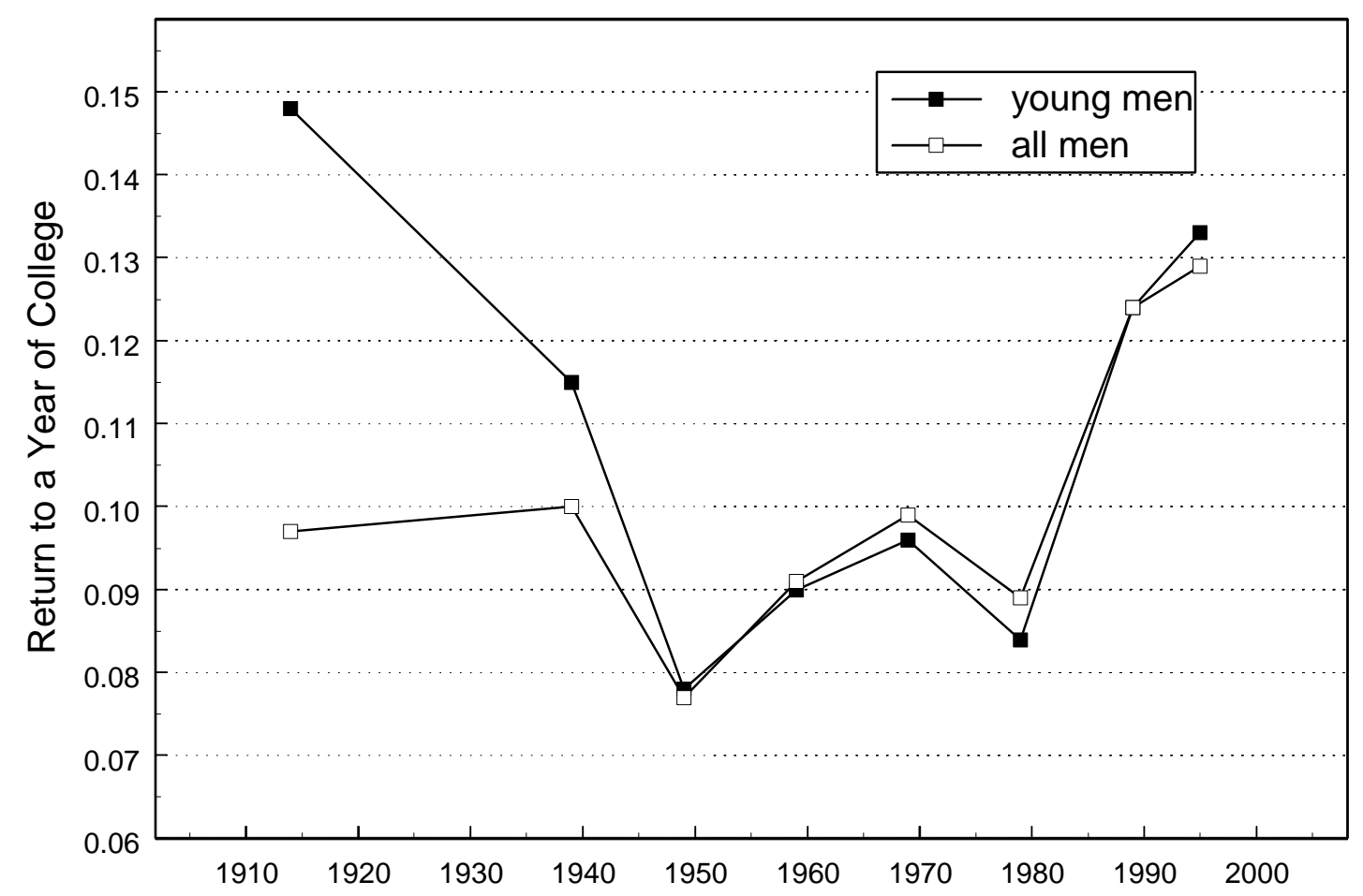

Sources and Notes: See Table 7. The 1914 estimate for each group is the average of the corresponding 1914 variant I and variant II estimates of the returns to college reported in Table 7. 
Table 1

Wage Structure Changes for Male Production Workers in Manufacturing, 1890 and 1940:

50/10, 90/50, and 90/10 Wage Ratios

\begin{tabular}{|c|c|c|c|c|c|c|c|c|}
\hline Industry & $\begin{array}{l}1890 \\
50 / 10 \\
\end{array}$ & $\begin{array}{l}c .1940 \\
50 / 10\end{array}$ & $\begin{array}{l}1890 \\
90 / 50 \\
\end{array}$ & $\begin{array}{c}c .1940 \\
90 / 50 \\
\end{array}$ & $\begin{array}{l}1890 \\
90 / 10 \\
\end{array}$ & $\begin{array}{c}c .1940 \\
90 / 10 \\
\end{array}$ & $\begin{array}{l}1890 \\
75 / 25\end{array}$ & $\begin{array}{l}c .1940 \\
75 / 25 \\
\end{array}$ \\
\hline cotton goods & 1.64 & 1.33 & 1.67 & 1.48 & 2.75 & 1.97 & 1.63 & 1.46 \\
\hline $\begin{array}{l}\text { dyeing \& finishing } \\
\text { textiles }\end{array}$ & 1.71 & 1.47 & 1.61 & 1.39 & 2.76 & 2.04 & 1.59 & 1.51 \\
\hline $\begin{array}{l}\text { flouring \& grist (grain, } \\
\text { 1940) mill products }\end{array}$ & 1.47 & 1.69 & 1.51 & 1.60 & 2.22 & 2.69 & 1.43 & 1.90 \\
\hline $\begin{array}{l}\text { foundry \& machine shop } \\
\text { products }\end{array}$ & 1.72 & 1.51 & 1.58 & 1.52 & 2.72 & 2.30 & 1.93 & 1.55 \\
\hline furniture, factory product & 1.75 & 1.43 & 1.63 & 1.68 & 2.85 & 2.40 & 1.70 & 1.67 \\
\hline iron and steel & 1.41 & 1.25 & 2.04 & 1.48 & 2.88 & 1.85 & 1.72 & 1.40 \\
\hline $\begin{array}{l}\text { lumber \& planing mill } \\
\text { products (no logging) }\end{array}$ & 1.80 & 1.30 & 1.52 & 1.93 & 2.73 & 2.51 & 1.91 & 1.97 \\
\hline $\begin{array}{l}\text { shipbuilding (private } \\
\text { shipyards, c. 1940) }\end{array}$ & 1.72 & 1.45 & 1.47 & 1.32 & 2.52 & 1.92 & 1.74 & 1.46 \\
\hline $\begin{array}{l}\text { silk \& silk goods (\& } \\
\text { rayon, c. 1940) }\end{array}$ & 2.06 & 1.38 & 1.61 & 1.62 & 3.32 & 2.23 & 1.80 & 1.62 \\
\hline soap (\& candles, 1890) & 1.97 & 1.51 & 1.48 & 1.33 & 2.90 & 2.01 & 1.55 & 1.35 \\
\hline $\begin{array}{l}\text { tobacco: chewing, } \\
\text { smoking, \& snuff ( } \& \\
\text { cigarettes, 1940) }\end{array}$ & 1.55 & 1.37 & 1.81 & 1.46 & 2.81 & 1.99 & 1.79 & 1.54 \\
\hline $\begin{array}{l}\text { tobacco: cigars (\& } \\
\text { cigarettes, 1890) }\end{array}$ & 2.01 & 1.49 & 1.54 & 1.66 & 3.11 & 2.48 & 1.70 & 1.68 \\
\hline $\begin{array}{l}\text { Weighted average (using } \\
1940 \text { employment } \\
\text { weights) }\end{array}$ & 1.66 & 1.35 & 1.71 & 1.60 & 2.81 & 2.15 & 1.74 & 1.60 \\
\hline
\end{tabular}

Sources and Notes: See Appendix Table 1. The Spring 1937 figures are used for "cotton goods." The "gray and malleable iron foundries" are used for c.1940. The 1941 figure is used for "furniture. An average of the two 1890 figures (with and without white-collar workers) is used for "tobacco: cigars." Cigarettes were unimportant in 1890 and were included with cigars for that year. By 1940, cigarettes were a majority of the tobacco industry employment. 
Table 2

Ratios of Clerical Worker Earnings to those of Production Workers in Manufacturing: by Sex and Occupation, 1890 to 1959

\begin{tabular}{|c|c|c|c|c|c|c|c|c|}
\hline \multirow[b]{3}{*}{ Year } & \multicolumn{8}{|c|}{ Ratio of earnings of clerical group to those of production workers in manufacturing } \\
\hline & \multicolumn{2}{|c|}{ All clericals } & \multicolumn{2}{|c|}{ Clerks } & \multicolumn{2}{|c|}{$\begin{array}{c}\text { Typists and } \\
\text { stenographers }\end{array}$} & \multicolumn{2}{|c|}{$\begin{array}{c}\text { Bookkeepers and } \\
\text { cashiers }\end{array}$} \\
\hline & Females & Males & Females & Males & Females & Males & Female & Male \\
\hline 1890 & 1.848 & - & - & - & - & - & - & - \\
\hline 1895 & 1.936 & 1.691 & 1.798 & 1.388 & 2.099 & 1.638 & 2.001 & 2.278 \\
\hline 1909 & 1.956 & 1.652 & - & - & - & - & - & - \\
\hline 1914 & 2.073 & 1.696 & - & - & - & - & - & - \\
\hline 1919 & 1.525 & 1.202 & - & - & - & - & - & - \\
\hline 1923 & 1.413 & 1.099 & - & - & - & - & - & - \\
\hline 1924 & 1.399 & 1.097 & - & - & - & - & - & - \\
\hline 1925 & 1.466 & 1.101 & - & - & - & - & - & - \\
\hline 1926 & 1.480 & 1.113 & 1.177 & 1.084 & 1.641 & 1.319 & 2.205 & 1.604 \\
\hline 1927 & 1.501 & 1.131 & - & - & - & - & - & - \\
\hline 1928 & 1.546 & 1.117 & - & - & - & - & - & - \\
\hline 1929 & 1.527 & 1.128 & - & - & - & - & - & - \\
\hline 1939 & 1.557 & 1.150 & 1.499 & 1.088 & 1.652 & 1.100 & 1.613 & 1.268 \\
\hline & \multicolumn{2}{|c|}{ All clericals } & & & \multicolumn{2}{|c|}{$\begin{array}{c}\text { Typists, stenographers, } \\
\text { and secretaries }\end{array}$} & \multicolumn{2}{|c|}{$\begin{array}{c}\text { Bookkeepers, cashiers, } \\
\text { and accountants }\end{array}$} \\
\hline 1939 & 1.369 & 1.187 & & & 1.430 & 1.288 & 1.309 & 1.341 \\
\hline 1949 & 1.137 & 1.076 & & & 1.166 & 1.333 & 1.131 & 1.236 \\
\hline 1959 & 1.133 & 1.019 & & & 1.171 & 1.168 & 1.097 & 1.188 \\
\hline
\end{tabular}

Sources: 1890 to 1939: Goldin and Katz (1995), tables 5 and 6. 1939 to 1959: Integrated Public Use Micro-data Samples (IPUMS) of the U.S. federal population censuses.

Notes: "All clericals" excludes supervisors. "Clerks" includes all clerks, except chief and senior clerks, file clerks, and mail clerks for 1895 and 1926. "Typists and stenographers" in 1895 includes secretaries, but excludes male secretaries with very high earnings. "Bookkeepers and cashiers" includes chief and senior clerks, accountants, and assistant bookkeepers for 1895 and 1926, and includes tellers in 1939. Occupational categories for the 1939 to 1959 series use the census definitions in each of the years given. "All clericals" excludes "clerks working in stores" in 1939. The production worker wages for the 1939 to 1959 series use only those working in the manufacturing sector. The wage ratios for 1939 to 1959 are for annual earnings of full time, full year workers (those working 35 or more hours per week and 50 or more weeks in the previous calendar year). Weekly wage ratios for all full time workers produce similar estimates in all cases for 1939 to 1959. 
Table 3

Ratios of the Earnings of Professionals (College Professors and Engineers)

to Wage and Salary Earners in Manufacturing or to Low-skilled Workers, 1900 to 1960

\begin{tabular}{|c|c|c|c|c|c|c|}
\hline \multicolumn{7}{|c|}{ Part A: College Professors } \\
\hline & \multicolumn{3}{|c|}{$\begin{array}{c}\text { Annual earnings (professors/ } \\
\text { average worker in manufacturing) }\end{array}$} & \multicolumn{3}{|c|}{$\begin{array}{l}\text { Annual earnings (professors/ } \\
\text { average low-skilled worker) }\end{array}$} \\
\hline Year & Full professor & $\begin{array}{l}\text { Associate } \\
\text { professor }\end{array}$ & $\begin{array}{l}\text { Assistant } \\
\text { professor }\end{array}$ & Full professor & $\begin{array}{l}\text { Assistant } \\
\text { professor }\end{array}$ & $\begin{array}{c}\text { Highest full } \\
\text { professor salary }\end{array}$ \\
\hline 1908 & 4.159 & 3.004 & 2.648 & 4.460 & 2.840 & 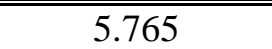 \\
\hline 1909 & 4.032 & 2.788 & 2.386 & 4.658 & 2.756 & 5.939 \\
\hline 1910 & 3.713 & 2.668 & 2.209 & 4.539 & 2.700 & - \\
\hline 1911 & 3.747 & 2.902 & 2.362 & 4.675 & 2.948 & - \\
\hline 1912 & 3.659 & 2.751 & 2.309 & 4.616 & 2.913 & 5.961 \\
\hline 1913 & 3.575 & 2.559 & 2.193 & 4.544 & 2.788 & - \\
\hline 1914 & 3.635 & 2.675 & 2.251 & 4.694 & 2.907 & 6.460 \\
\hline 1915 & 3.903 & 2.849 & 2.396 & 4.845 & 2.975 & 6.659 \\
\hline 1916 & 3.406 & 2.491 & 2.156 & 3.713 & 2.350 & 5.035 \\
\hline 1917 & 3.014 & 2.202 & 1.866 & 3.098 & 1.919 & 3.972 \\
\hline 1918 & 2.418 & 1.818 & 1.548 & 2.468 & 1.580 & 3.364 \\
\hline 1919 & 2.175 & 1.688 & 1.366 & 2.360 & 1.482 & 3.319 \\
\hline 1920 & 2.129 & 1.597 & 1.320 & 2.511 & 1.557 & 3.310 \\
\hline 1921 & 2.686 & 2.039 & 1.734 & 3.566 & 2.302 & 4.868 \\
\hline 1922 & 2.989 & 2.344 & 1.936 & 3.778 & 2.447 & 5.408 \\
\hline 1923 & 2.817 & 2.173 & 1.816 & 3.548 & 2.287 & 4.994 \\
\hline 1924 & 2.809 & 2.161 & 1.786 & 3.578 & 2.274 & 5.060 \\
\hline 1925 & - & - & - & - & - & 5.256 \\
\hline 1926 & 2.786 & 2.141 & 1.782 & 3.543 & 2.266 & 5.017 \\
\hline 1927 & 2.816 & 2.128 & 1.781 & 3.594 & 2.273 & 4.914 \\
\hline 1928 & 2.821 & 2.150 & 1.786 & 3.622 & 2.293 & 5.102 \\
\hline 1929 & 2.818 & 2.177 & 1.744 & 3.564 & 2.206 & 5.349 \\
\hline 1930 & 2.962 & 2.248 & 1.865 & 4.025 & 2.534 & 6.094 \\
\hline 1931 & 3.272 & 2.497 & 2.056 & 4.672 & 2.935 & 7.055 \\
\hline 1932 & 3.917 & 2.938 & 2.435 & 6.222 & 3.867 & 8.559 \\
\hline 1935 & 3.104 & 2.387 & 2.014 & 4.121 & 2.674 & - \\
\hline 1936 & 3.070 & 2.310 & 1.932 & 3.951 & 2.486 & - \\
\hline 1937 & 3.028 & 2.285 & 1.858 & 3.718 & 2.281 & - \\
\hline 1938 & 3.212 & 2.461 & 2.000 & 4.028 & 2.508 & - \\
\hline 1940 & 2.964 & 2.285 & 1.819 & 3.551 & 2.179 & - \\
\hline 1942 & 2.127 & 1.643 & 1.307 & 2.569 & 1.580 & - \\
\hline 1949 & 2.145 & 1.667 & 1.363 & - & - & - \\
\hline 1950 & 2.183 & 1.670 & 1.361 & - & - & - \\
\hline 1952 & 2.061 & 1.577 & 1.283 & - & - & - \\
\hline 1954 & 2.115 & 1.579 & 1.281 & - & - & - \\
\hline 1956 & 2.003 & 1.472 & 1.197 & - & - & - \\
\hline 1958 & 2.093 & 1.551 & 1.258 & - & - & - \\
\hline 1960 & 2.145 & 1.585 & 1.277 & - & - & - \\
\hline
\end{tabular}


Goldin \& Katz, draft of 5/17/1999 -40-

\begin{tabular}{|c|c|c|c|c|c|}
\hline \multicolumn{6}{|c|}{ Part B: Engineers } \\
\hline & \multicolumn{5}{|c|}{ Annual earnings (engineers/manufacturing workers) } \\
\hline Year & $\begin{array}{c}1) \\
\text { Starting } \\
\text { engineers }\end{array}$ & $\begin{array}{c}(2) \\
\text { Starting } \\
\text { engineers }\end{array}$ & $\begin{array}{c}\text { (3) } \\
\text { First year } \\
\text { engineers }\end{array}$ & $\begin{array}{c}\text { (4) } \\
\text { Second year } \\
\text { engineers }\end{array}$ & $\begin{array}{c}\text { (5) } \\
\text { All engineers, } \\
\text { median monthly } \\
\mathrm{H} 12\end{array}$ \\
\hline 1900 & - & - & 1.643 & - & - \\
\hline 1901 & - & - & - & 2.104 & - \\
\hline 1904 & 1.338 & - & - & - & - \\
\hline 1905 & - & - & 1.604 & - & - \\
\hline 1906 & - & - & - & 2.080 & - \\
\hline 1909 & 1.202 & - & - & - & - \\
\hline 1910 & - & - & 1.382 & - & - \\
\hline 1911 & - & - & - & 1.899 & - \\
\hline 1914 & 1.149 & - & - & - & - \\
\hline 1915 & - & - & 1.513 & - & - \\
\hline 1916 & - & - & - & 1.598 & - \\
\hline 1919 & 1.005 & - & - & - & - \\
\hline 1920 & - & - & 1.175 & - & - \\
\hline 1921 & - & - & - & 1.486 & - \\
\hline 1922 & 1.029 & - & - & - & - \\
\hline 1923 & 1.026 & - & 1.283 & - & - \\
\hline 1924 & 1.034 & - & 1.261 & 1.472 & - \\
\hline 1929 & - & 1.037 & - & - & 2.248 \\
\hline 1932 & - & 1.037 & - & - & 2.452 \\
\hline 1934 & - & 1.024 & - & - & 2.186 \\
\hline 1939 & - & 1.008 & - & - & 2.439 \\
\hline 1943 & - & 0.997 & - & - & 1.706 \\
\hline 1946 & - & 0.985 & - & - & 1.950 \\
\hline 1947 & 1.048 & - & - & - & - \\
\hline 1948 & 0.987 & - & - & - & - \\
\hline 1949 & 1.012 & - & - & - & - \\
\hline 1950 & 0.945 & - & - & - & - \\
\hline 1951 & 0.898 & - & - & - & - \\
\hline 1952 & 0.955 & - & - & - & - \\
\hline 1953 & 0.962 & - & - & - & 1.534 \\
\hline 1954 & 1.004 & - & - & - & - \\
\hline 1955 & 0.994 & - & - & - & - \\
\hline 1956 & 1.030 & - & - & - & - \\
\hline
\end{tabular}




\section{Sources and Notes:}

The year given is the end of the academic year.

Professors

Full, Associate, Assistant: All are 9 to 10 month salaries and are the average of the medians for land-grant institutions. 1908 to 1934: 26 land-grant institutions from Stigler (1950, table 28), which relies on Boothe (1932) but makes various revisions; 1935 to 1942: 51 land-grant institutions, from Stigler (1950, table 28); 1949 to 1960: American Association of University Professors (various years), 6 or 7 land-grant institutions, 5 in 1960. The maximum salary figures for full professors ("highest full professor salary") are from Boothe (1932, table IV) for 1914 to 1932, and from U.S. Bureau of Education (various years) for 1908 to 1912. The maximum figures are also given because Boothe constructed the median figures for 1914 to 1921 by extrapolating from the relationship between the maximum and the median for the period after 1922. All of the Boothe data are derived from those in the U.S. Bureau of Education publications. Manufacturing employees

U.S. Bureau of the Census (1975), series D 740, due to S. Lebergott, average annual earnings per fulltime employee (wage and salary earners).

Low-skilled workers

1908 to 1920, U.S. Bureau of the Census (1975), series D 778, due to Coombs; 1921 to 1948, U.S.

Bureau of the Census (1975), series D 841, due to N.I.C.B., agrees with Coombs data for 1914 and 1920. Engineeers

1900 to 1924: cols. (1), (3), (4), starting, 1 year, and 2 year salaries (where years refer to engineering job experience) from Blank and Stigler (1957, table A-4).

1947 to 1956: col. (1) starting salaries, Blank and Stigler (1957, table A-14) monthly times 12.

1929 to 1946: col. (2), Blank and Stigler (1957, table A-8), gives an index of starting salaries (less than 1 year of engineering job experience). We have spliced this series to that in col. (1) such that the 1929 ratio is approximately equal to that in 1924.

1929 to 1946: col. (5), Blank and Stigler (1957, table A-1), median monthly salaries for all engineers; the 1943 figure excludes overtime.

1953: col. (5), Blank and Stigler (1957, table A-2). 
Table 4

Formal Schooling Indicators in 1915 Iowa and 1940 United States:

by Sex for 25 to 59 Year Olds

\begin{tabular}{|l|c|c|c|c|}
\hline \hline & \multicolumn{2}{|c|}{ Males, 25 to 59 years old } & \multicolumn{2}{c|}{ Females, 25 to 59 years old } \\
\cline { 2 - 5 } & 1915 Iowa & $\begin{array}{c}\text { 1940 United } \\
\text { States }\end{array}$ & 1915 Iowa & $\begin{array}{c}\text { 1940 United } \\
\text { States }\end{array}$ \\
\hline \hline Mean highest grade completed (I) & 8.40 & & 8.68 & \\
Mean highest grade completed (II) & 8.56 & 8.60 & 8.86 & 8.86 \\
Average years of education & 8.61 & & 8.98 & \\
\hline Fraction with less than 8 years & 0.235 & 0.311 & 0.185 & 0.278 \\
\hline Fraction with some high school (I) & 0.233 & 0.410 & 0.290 & 0.462 \\
Fraction with some high school (II) & 0.379 & & 0.446 & \\
\hline Fraction graduating high school (I) & 0.152 & 0.248 & 0.179 & 0.287 \\
Fraction graduating high school (II) & 0.156 & & 0.184 & \\
\hline \hline
\end{tabular}

\section{Notes and Sources:}

1915: Iowa 1915 sample (see Goldin and Katz 1999b). The assessors asked the "extent of education" in years, in common school, grammar school, high school, and college listed separately.

1940: IPUMS. The enumerators were asked to inquire "what is the highest grade of school completed." The instruction to the enumerators explains: "This question refers only to the education obtained in public, private, or parochial schools, colleges, or universities. Education obtained at vocational schools is not to be considered, unless such school or college was part of the regular school system. ... Enter [college 1 through 5] whether or not the person was graduated from high school. For persons whose highest grade completed was in a junior high school, it will be necessary to ascertain the equivalent in terms of ... grades." (ICPSR 1984, 6.40-6.41). The highest grade of school cannot exceed seventeen.

Mean highest grade completed [1915]: reconstructs the 1915 data to approximate the 1940 instructions to enumerators. In agreement with the 1940 census, the highest grade is truncated at seventeen. Consistent with the instructions to enumerators, if an individual attended eight years of grammar school and four years of college but no high school, for example, the individual received 16 years of schooling, rather than 12. For version (I) no individual in 1915 is given years of education beyond eight for the sum of common and grammar school years. For version (II) the cutoff is nine years.

Average years of education: the sum of years of schooling in the various school categories with a truncation at seventeen years.

Fraction with some high school [1915]: fraction with years of education equal to at least nine. Version (I) and (II) differ in the same manner as for mean highest grade completed [1915].

Fraction with some high school [1940]: fraction with highest grade completed equal to at least nine.

Fraction graduating high school [1915]: fraction with years of education equal to at least twelve.

Version (I) and (II) differ in the same manner as for mean highest grade completed [1915].

Fraction graduating high school [1940]: fraction with years of education equal to at least twelve. 
Table 5

Returns to Education by Type of Schooling, Iowa 1914:

Males, 18 to 65 years old by Farm and Non-Farm Occupations

\begin{tabular}{|c|c|c|c|c|c|c|}
\hline & \multicolumn{3}{|c|}{ Males, 18 to 65 years old } & \multicolumn{3}{|c|}{ Males, 18 to 34 years old } \\
\hline & $\begin{array}{c}\text { (1) } \\
\text { All } \\
\text { occupations }\end{array}$ & $\begin{array}{c}(2) \\
\text { Non-farm } \\
\text { occupations }\end{array}$ & $\begin{array}{c}\text { (3) } \\
\text { Farm } \\
\text { occupations }\end{array}$ & $\begin{array}{c}(4) \\
\text { All } \\
\text { occupations }\end{array}$ & $\begin{array}{c}\text { (5) } \\
\text { Non-farm } \\
\text { occupations }\end{array}$ & $\begin{array}{c}(6) \\
\text { Farm } \\
\text { occupations }\end{array}$ \\
\hline Common school, & 0.0427 & 0.040 & 0.0375 & 0.0483 & 0.0375 & 0.0637 \\
\hline $\begin{array}{l}\text { years } \\
\text { Grammar school, }\end{array}$ & $\begin{array}{c}(0.00269) \\
0.0533\end{array}$ & $\begin{array}{c}(0.00300) \\
0.0647\end{array}$ & $\begin{array}{c}(0.00555) \\
0.0232\end{array}$ & $\begin{array}{c}(0.00395) \\
0.0693\end{array}$ & $\begin{array}{c}(0.00442) \\
0.0671\end{array}$ & $\begin{array}{c}(0.00837) \\
0.0568\end{array}$ \\
\hline years & $(0.00292)$ & $(0.00304)$ & $(0.00800)$ & $(0.00421)$ & $(0.00443)$ & $(0.0110)$ \\
\hline High school, years & 0.103 & 0.102 & 0.114 & 0.120 & 0.114 & 0.132 \\
\hline & $(0.00448)$ & $(0.00401)$ & $(0.0146)$ & $(0.00564)$ & $(0.00516)$ & $(0.0176)$ \\
\hline College, years & 0.103 & 0.106 & 0.132 & 0.146 & 0.143 & 0.166 \\
\hline & $(0.00604)$ & $(0.00520)$ & $(0.0254)$ & $(0.00915)$ & (0.00799) & $(0.0381)$ \\
\hline Business school, & 0.379 & 0.393 & & 0.284 & 0.273 & \\
\hline dummy & $(0.0850)$ & $(0.0705)$ & & $(0.0988)$ & $(0.0831)$ & \\
\hline Native born & 0.222 & 0.178 & 0.262 & 0.210 & 0.145 & 0.284 \\
\hline & $(0.0252)$ & $(0.0253)$ & $(0.0593)$ & $(0.0324)$ & $(0.0330)$ & $(0.0766)$ \\
\hline (Years in U.S. $\mathrm{H} 10^{-2}$ ) & 0.677 & 0.409 & 0.913 & 1.14 & 0.497 & 1.78 \\
\hline $\mathrm{H}$ foreign born & $(0.0923)$ & $(0.0943)$ & $(0.218)$ & $(0.223)$ & $(0.238)$ & $(0.489)$ \\
\hline $\mathrm{R}^{2}$ & 0.199 & 0.256 & 0.209 & 0.251 & 0.296 & 0.241 \\
\hline Standard error & 0.624 & 0.546 & 0.702 & 0.567 & 0.501 & 0.645 \\
\hline $\begin{array}{l}\text { Number of } \\
\text { observations }\end{array}$ & 14,699 & 10,695 & 3,705 & 7,145 & 5,249 & 1,784 \\
\hline
\end{tabular}

Source: Iowa 1915 sample (see Goldin and Katz 1999b, Appendix).

Notes: Sample excludes bottom 0.2 percent of the earnings distribution (less than \$60) and is restricted to those out of school. Regressions also contain a quartic in potential experience, a race dummy, and a dummy variable for those missing "years in U.S." Potential experience is defined as min(age - 15, age years of schooling - 7). All regressions are weighted by urban and rural sampling weights (see Goldin and Katz 1999b, Appendix, for weighting information). Figures in parentheses are standard errors. 
Table 6

Returns to Education for Full Year, Non-farm, Male Workers in Iowa:

1914, 1939, 1949, and 1959

\begin{tabular}{|c|c|c|c|c|c|c|}
\hline \multirow[t]{2}{*}{ Census year } & \multicolumn{2}{|c|}{ Years of high school } & \multicolumn{2}{|c|}{ Years of college } & \multicolumn{2}{|c|}{$\begin{array}{c}\text { Linear in all years of } \\
\text { schooling }\end{array}$} \\
\hline & $\begin{array}{c}18-65 \\
\text { years old }\end{array}$ & $\begin{array}{c}18-34 \\
\text { years old }\end{array}$ & $\begin{array}{c}18-65 \\
\text { years old }\end{array}$ & $\begin{array}{c}18-34 \\
\text { years old }\end{array}$ & $\begin{array}{c}18-65 \\
\text { years old }\end{array}$ & $\begin{array}{c}18-34 \\
\text { years old }\end{array}$ \\
\hline (1) 1915 & 0.091 & 0.105 & 0.091 & 0.128 & 0.084 & 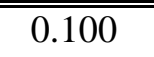 \\
\hline (2) 1950 & 0.051 & 0.067 & 0.073 & 0.086 & 0.054 & 0.069 \\
\hline (3) 1960 & 0.047 & 0.050 & 0.085 & 0.071 & 0.059 & 0.058 \\
\hline (4) 1940, wage and & 0.064 & 0.097 & 0.081 & 0.086 & 0.064 & 0.075 \\
\hline $\begin{array}{l}\text { (5) } 1950 \text {, wage and } \\
\text { salary earnings only }\end{array}$ & 0.049 & 0.043 & 0.064 & 0.101 & 0.048 & 0.060 \\
\hline (6) 1960 , wage and & 0.040 & 0.049 & 0.064 & 0.057 & 0.046 & 0.050 \\
\hline (7) 1940 , adjusted & 0.064 & 0.097 & 0.094 & 0.095 & 0.068 & 0.079 \\
\hline
\end{tabular}

Sources: Iowa 1915 Sample; 1940, 1950, and 1960 IPUMS.

Notes:

See Appendix Table 2 for standard errors and for the other schooling coefficients. Coefficients listed for "years of high school" and "years of college" are those from a spline in years of education (1 to 8 years, 9 to 12 years, and 13 plus years) in a regression of (log) annual earnings. Coefficients listed for "linear in years of all schooling" are those from the sum of all years in school in a regression of (log) annual earnings. "Full year" is defined for 1940, 1950, and 1960 as more than 49 weeks of work; in 1915 it is defined as listing no unemployment. Controls in all regressions are: quartic in potential experience, whether native born, and whether white. Each of the samples deletes the lowest 1 percent of earners. The samples for 1940, 1950, and 1960 include only those living in the state of Iowa.

The 1940 adjusted estimates, row (7), take the 1940 wage and salary earnings estimates, row (4), and add an adjustment factor to account for the absence of self employment income, for comparability with the estimates in row (1) for 1915. The adjustment factor, for each column, is constructed from national estimates because the sample used here (for Iowa) is small, particularly for 1950. We take the difference in returns to each type of schooling for the entire sample and for the wage and salary sample, averaging the estimates for 1950 and 1960, and then add this adjustment factor to the 1940 estimates in row (4). 
Table 7

Returns to Education for Full Year, Non-farm, Male Workers in the United States: 1914 to 1995

\begin{tabular}{|c|cc|cc|}
\hline \hline \multirow{2}{*}{ Year } & \multicolumn{4}{|c|}{ Returns to a year of: } \\
\cline { 2 - 5 } & \multicolumn{3}{|c|}{ High school } & \multicolumn{2}{c|}{ College } \\
\cline { 2 - 5 } & Young men & All men & Young men & All men \\
\hline \hline 1914, variant I & 0.110 & 0.112 & 0.148 & 0.097 \\
1914, variant II & 0.125 & 0.098 & 0.148 & 0.097 \\
1939 & 0.102 & 0.085 & 0.115 & 0.100 \\
1949 & 0.054 & 0.051 & 0.078 & 0.077 \\
1959 & 0.070 & 0.054 & 0.090 & 0.091 \\
1969 & 0.074 & 0.059 & 0.096 & 0.099 \\
1979 & 0.081 & 0.066 & 0.084 & 0.089 \\
1989 & 0.093 & 0.078 & 0.124 & 0.124 \\
1995 & 0.096 & 0.081 & 0.133 & 0.129 \\
\hline \hline
\end{tabular}

Notes and Sources:

"Young" means 0 to 19 years of potential work experience. "All" means 0 to 39 years of potential work experience. The estimates of returns to high school and college refer to composition-adjusted log weekly wage differentials by years of schooling for full-time, full-year male wage and salary workers. The approach to estimating these educational wage differentials from 1939 to 1995 is the same as the methodology described for estimating returns to college in the notes to Figure 1. See Katz and Autor (1999, forthcoming).

Returns to High School: 1915 Iowa sample (see Goldin and Katz 1999b); 1940 to 1970 IPUMS; and 1970 to 1996 March CPS. The estimates from 1939 to 1969 equal the composition-adjusted log weekly wage differential between workers with exactly 12 and exactly 9 years of schooling divided by 3 , using data from the 1940 to 1970 IPUMS. The changes in returns from 1969 to 1995 equal one-half times the change in the composition-adjusted log weekly wage differential of workers with exactly 12 years of schooling (or exactly a high school degree) and exactly 10 years of schooling using data from the 1970 to 1996 March CPS. The 1914, variant I estimate for each group equals the sum of our 1939 national estimate for that group and the corresponding estimated change in returns to a year of high school in Iowa from 1914 to 1939 (the difference between rows 1 and 7 for the relevant columns in Table 6). The 1914, variant II estimate equals the sum of our 1959 national estimate for that group and the corresponding estimated change in returns to a year of high school in Iowa from 1914 to 1959 (the difference between rows 1 and 3 for the relevant columns in Table 6).

Returns to College: 1915 Iowa sample; 1940 to 1990 IPUMS; and 1990 and 1996 March CPS. The methodology for the estimates from 1939 to 1995 is described in the notes to Figure 1. The 1914, variant I and variant II estimates of returns to college use the same methodology as used for the analogous 1914 estimates for returns to high school. The 1914, variant I estimates add the corresponding 1914 to 1939 changes in college returns for Iowa from Table 6 to our 1939 national estimates. The 1914, variant II estimates similarly add the corresponding 1914 to 1959 changes in college returns for Iowa from Table 6 to our 1959 national estimates. 
Appendix Table 1

Wage Distribution for Male Production Workers in Twelve Manufacturing Industries, 1890 and c.1940

\begin{tabular}{|c|c|c|c|c|c|c|c|c|c|}
\hline Industry & $\begin{array}{c}\text { Date } \\
\text { month, year }\end{array}$ & $\begin{array}{c}\text { Wage at } \\
10 \%\end{array}$ & $\begin{array}{c}\text { Wage at } \\
25 \%\end{array}$ & $\begin{array}{l}\text { Wage at } \\
\text { median }\end{array}$ & $\begin{array}{c}\text { Wage at } \\
75 \%\end{array}$ & $\begin{array}{c}\text { Wage at } \\
90 \%\end{array}$ & $\begin{array}{c}\text { number } \\
\text { blue-collar } \\
\text { (sample) }\end{array}$ & $\begin{array}{c}\text { number white- } \\
\text { collar } \\
\text { (1890 sample) } \\
\end{array}$ & $\begin{array}{l}\text { \% white- } \\
\text { collar }\end{array}$ \\
\hline \multirow[t]{3}{*}{ cotton goods } & 1890 & 4.71 & 6.09 & 7.74 & 9.94 & 12.94 & 43,187 & 1,184 & 2.6 \\
\hline & Spring 1937 & 30.19 & 34.50 & 40.21 & 50.47 & 59.52 & 56,453 & & \\
\hline & 1940 & 32.50 & 32.60 & 38.10 & 48.30 & 56.02 & 56,117 & & \\
\hline \multirow[t]{2}{*}{ dyeing \& finishing textiles } & 1890 & 5.42 & 7.34 & 9.27 & 11.68 & 14.94 & 8,978 & 447 & 4.7 \\
\hline & Sept. 1940 & 35.99 & 42.90 & 52.90 & 64.88 & 73.41 & 24,560 & & \\
\hline flouring \& grist mill & 1890 & 7.42 & 9.25 & 10.93 & 13.25 & 16.49 & 9,108 & 1,734 & 16.0 \\
\hline grain mill products $^{\mathrm{a}}$ & Feb. 1941 & 30.00 & 35.76 & 50.54 & 67.79 & 80.71 & 19,100 & & \\
\hline foundry \& machine shop & 1890 & 6.56 & 7.60 & 11.29 & 14.68 & 17.84 & 150,219 & 11,368 & 7.0 \\
\hline \multirow{2}{*}{$\begin{array}{l}\text { foundries (gray iron) } \\
\text { (gray \& malleable iron) }\end{array}$} & \multirow{2}{*}{$\begin{array}{l}\text { late } 1938- \\
\text { early1939 }\end{array}$} & 41.86 & 51.53 & 64.22 & 81.32 & 99.11 & 36,749 & & \\
\hline & & 42.83 & 52.46 & 64.58 & 81.08 & 98.31 & 42,906 & & \\
\hline \multirow{4}{*}{$\begin{array}{l}\text { furniture, factory product } \\
\text { (1890), mass produced } \\
\text { (c.1940), mainly wood }\end{array}$} & 1890 & 6.17 & 8.21 & 10.77 & 13.93 & 17.58 & 36,735 & 2,248 & 5.7 \\
\hline & Oct. $1937^{\mathrm{c}}$ & 30.14 & 35.00 & 44.34 & 58.93 & 74.77 & 33,199 & & \\
\hline & Oct. $1937^{\mathrm{c}}$ & 30.21 & 35.18 & 45.32 & 60.25 & 75.97 & 9,690 & & \\
\hline & Feb. 1941 & 31.29 & 35.18 & 44.66 & 58.86 & 75.14 & 10,430 & & \\
\hline \multirow[t]{2}{*}{ iron and steel } & 1890 & 7.08 & 8.27 & 10.01 & 14.19 & 20.38 & 168,943 & $\bar{d}$ & \\
\hline & Apr. 1938 & 62.50 & 67.13 & 78.13 & 93.80 & 115.71 & 80,711 & & \\
\hline lumber \& planing mill & 1890 & 6.48 & 7.69 & 11.65 & 14.66 & 17.72 & 50,064 & 3,870 & 7.2 \\
\hline \multirow{2}{*}{$\begin{array}{l}\text { lumber \& timber products } \\
\text { without logging }\end{array}$} & \multirow[t]{2}{*}{ 1939-1940 } & 30.53 & 31.69 & 41.31 & 65.11 & 82.16 & 105,362 & & \\
\hline & & 30.48 & 31.55 & 39.68 & 62.22 & 76.60 & 84,351 & & \\
\hline \multirow{2}{*}{$\begin{array}{l}\text { shipbuilding: private ship yards } \\
\text { c. } 1940\end{array}$} & 1890 & 7.56 & 9.56 & 13.01 & 16.62 & 19.08 & 23,499 & 1,112 & 4.5 \\
\hline & Aug. $1936^{\mathrm{e}}$ & 50.95 & 60.14 & 73.89 & 87.96 & 97.83 & 25,324 & & \\
\hline silk \& silk goods & 1890 & 5.61 & 8.44 & 11.58 & 15.15 & 18.63 & 7,526 & 900 & 10.7 \\
\hline silk \& rayon goods & Sept. 1940 & 32.50 & 35.58 & 44.83 & 57.73 & 72.40 & 9,914 & & \\
\hline soap \& candles & 1890 & 4.90 & 7.55 & 9.64 & 11.71 & 14.23 & 5,454 & 1,228 & 18.4 \\
\hline soap & Jan. 1938 & 48.28 & 61.93 & 72.82 & 83.58 & 96.88 & 6,087 & & \\
\hline tobacco: chew, smoke, \& snuff & 1890 & 4.54 & 5.28 & 7.04 & 9.43 & 12.76 & 6,363 & 948 & 13.0 \\
\hline $\begin{array}{l}\text { tobacco: cigarette, chew, } \\
\text { smoke, \& snuff }\end{array}$ & Dec. 1940 & 41.13 & 46.88 & 56.25 & 72.22 & 81.87 & 16,339 & & \\
\hline \multirow[t]{2}{*}{ tobacco: cigars \& cigarettes ${ }^{b}$} & 1890 & 4.70 & 6.70 & 8.97 & 10.60 & 11.53 & 12,460 & 8,307 & 40.0 \\
\hline & 1890 & 5.29 & 8.16 & 11.12 & 14.89 & 19.92 & 20,767 & 0 & 0 \\
\hline tobacco: cigars & Winter 1940 & 30.51 & 35.94 & 45.54 & 59.96 & 75.63 & 9,577 & & \\
\hline
\end{tabular}


Appendix Table 1 (continued)

\begin{tabular}{|c|c|c|c|c|c|}
\hline Industry & $\begin{array}{c}\text { Date } \\
\text { month, year }\end{array}$ & $50 / 10$ & $90 / 50$ & $90 / 10$ & $75 / 25$ \\
\hline \multirow[t]{3}{*}{ cotton goods } & 1890 & 1.641 & 1.672 & 2.745 & 1.632 \\
\hline & Spring 1937 & 1.332 & 1.480 & 1.972 & 1.463 \\
\hline & 1940 & 1.175 & 1.470 & 1.724 & 1.482 \\
\hline \multirow[t]{2}{*}{ dyeing \& finishing textiles } & 1890 & 1.711 & 1.613 & 2.759 & 1.591 \\
\hline & Sept. 1940 & 1.470 & 1.388 & 2.040 & 1.512 \\
\hline flouring \& grist mill & 1890 & 1.472 & 1.508 & 2.221 & 1.433 \\
\hline grain mill products $^{\mathrm{a}}$ & Feb. 1941 & 1.685 & 1.597 & 2.690 & 1.896 \\
\hline foundry \& machine shop & 1890 & 1.721 & 1.580 & 2.720 & 1.931 \\
\hline $\begin{array}{l}\text { foundries (gray iron) } \\
\text { (gray \& malleable iron) }\end{array}$ & $\begin{array}{l}\text { late } 1938- \\
\text { early1939 }\end{array}$ & $\begin{array}{l}1.534 \\
1.508 \\
\end{array}$ & $\begin{array}{l}1.543 \\
1.522 \\
\end{array}$ & $\begin{array}{l}2.368 \\
2.295 \\
\end{array}$ & $\begin{array}{l}1.578 \\
1.546 \\
\end{array}$ \\
\hline \multirow{4}{*}{$\begin{array}{l}\text { furniture, factory product } \\
\text { (1890), mass produced } \\
\text { (c.1940), mainly wood }\end{array}$} & 1890 & 1.745 & 1.632 & 2.848 & 1.697 \\
\hline & Oct. $1937^{\mathrm{c}}$ & 1.471 & 1.686 & 2.481 & 1.684 \\
\hline & Oct. $1937^{\mathrm{c}}$ & 1.500 & 1.676 & 2.514 & 1.713 \\
\hline & Feb. 1941 & 1.427 & 1.683 & 2.401 & 1.673 \\
\hline \multirow[t]{2}{*}{ iron and steel } & 1890 & 1.414 & 2.036 & 2.879 & 1.716 \\
\hline & Apr. 1938 & 1.250 & 1.481 & 1.851 & 1.397 \\
\hline lumber \& planing mill & 1890 & 1.797 & 1.521 & 2.734 & 1.905 \\
\hline \multirow{2}{*}{$\begin{array}{l}\text { lumber \& timber products } \\
\text { without logging }\end{array}$} & \multirow[t]{2}{*}{$1939-1940$} & 1.353 & 1.989 & 2.691 & 2.055 \\
\hline & & 1.302 & 1.930 & 2.513 & 1.972 \\
\hline \multirow{2}{*}{$\begin{array}{l}\text { shipbuilding: private ship } \\
\text { yards c. } 1940\end{array}$} & 1890 & 1.721 & 1.467 & 2.524 & 1.738 \\
\hline & Aug. $1936^{\mathrm{e}}$ & 1.450 & 1.324 & 1.920 & 1.463 \\
\hline silk \& silk goods & 1890 & 2.062 & 1.609 & 3.318 & 1.795 \\
\hline silk \& rayon goods & Sept. 1940 & 1.379 & 1.615 & 2.228 & 1.623 \\
\hline soap \& candles & 1890 & 1.967 & 1.476 & 2.903 & 1.550 \\
\hline soap & Jan. 1938 & 1.508 & 1.330 & 2.007 & 1.349 \\
\hline $\begin{array}{l}\text { tobacco: chew, smoke, \& } \\
\text { snuff }\end{array}$ & 1890 & 1.551 & 1.811 & 2.809 & 1.786 \\
\hline $\begin{array}{l}\text { tobacco: cigarette, chew, } \\
\text { smoke, \& snuff }\end{array}$ & Dec. 1940 & 1.368 & 1.455 & 1.990 & 1.541 \\
\hline \multirow[t]{2}{*}{ tobacco: cigars \& cigarettes ${ }^{b}$} & 1890 & 1.909 & 1.286 & 2.455 & 1.582 \\
\hline & 1890 & 2.102 & 1.792 & 3.766 & 1.826 \\
\hline tobacco: cigars & Winter 1940 & 1.492 & 1.661 & 2.479 & 1.683 \\
\hline
\end{tabular}




\section{Sources:}

1890: All industries except "iron and steel" and shipbuilding from U.S. Bureau of the Census (1895a); "iron and steel" and shipbuilding from U.S. Bureau of the Census (1895b).

c.1940: Bureau of Labor Statistics, Monthly Labor Review (various issues).

Notes:

Wages are expressed in current dollars/week for 1890 and current cents/hour in c.1940. Data include male employees only, except where noted. For 1890 the data (except for "iron and steel" and shipbuilding) are from a sample of the 165 largest cities (but note that all twelve industries were not represented in all 165 cities). In 1890 all white-collar male employees (firm officers, supervisors, etc. and clerks) are subtracted from the distribution from the top down. If the lowest group (less than \$5) exhausts the bottom $10 \%$ (as it did in the cases of cotton goods, soap, and tobacco) we assume the range is [4 to 5). A uniform distribution within all groups is assumed. In no case was there a problem with the (open-ended) highest group. In only one case (cigars) was there good reason not to subtract the white-collar workers since $40 \%$ of the total male employees are in the non-production group and it is likely that many were owner-operator cigar makers. For c.1940 there was a binding spike at the first decile in furniture and grain mill products.

${ }^{a}$ There were very few women working in grain mill products (cereals employed some women, few were in flour milling) and furniture. The 1941 data for both these industries are for all workers.

${ }^{b}$ Both with and without white-collar workers distributions are given because $40 \%$ of male employees are whitecollar workers in this industry.

${ }^{\mathrm{c}}$ The smaller sample (second set of numbers) of the Oct. 1937 data are for the same plants as in Feb. 1941; the larger sample (first set of numbers) is the entire Oct. 1937 sample.

d The wage distribution for "iron and steel" is for the entire United States and is given without officers, clerks, and other non-production workers.

${ }^{\mathrm{e}}$ Hourly basic rate without drafting and supervisory employees. 
Appendix Table 2

Returns to Education for Full Year, Non-Farm, Male Workers in Iowa:

$1915,1940,1950$, and 1960

\begin{tabular}{|c|c|c|c|c|c|c|c|c|c|c|c|c|}
\hline & \multicolumn{6}{|c|}{18 to 65 years old } & \multicolumn{6}{|c|}{18 to 34 years old } \\
\hline & 1915 & $\begin{array}{c}1940, \\
\text { wage and } \\
\text { salary }\end{array}$ & 1950 & $\begin{array}{c}1950, \\
\text { wage and } \\
\text { salary }\end{array}$ & 1960 & $\begin{array}{c}1960, \\
\text { wage and } \\
\text { salary }\end{array}$ & 1915 & $\begin{array}{c}1940, \\
\text { wage and } \\
\text { salary }\end{array}$ & 1950 & $\begin{array}{c}1950, \\
\text { wage and } \\
\text { salary }\end{array}$ & 1960 & $\begin{array}{c}1960, \\
\text { wage and } \\
\text { salary }\end{array}$ \\
\hline $\begin{array}{l}\text { Years of } \\
\text { education }\end{array}$ & $\begin{array}{c}0.084 \\
(0.0019)\end{array}$ & $\begin{array}{c}0.064 \\
(0.0042)\end{array}$ & $\begin{array}{c}0.054 \\
(0.0060)\end{array}$ & $\begin{array}{c}0.048 \\
(0.0062)\end{array}$ & $\begin{array}{c}0.059 \\
(0.0030)\end{array}$ & $\begin{array}{c}0.046 \\
(0.0028)\end{array}$ & $\begin{array}{c}0.100 \\
(0.0028)\end{array}$ & $\begin{array}{c}0.075 \\
(0.0069)\end{array}$ & $\begin{array}{c}0.069 \\
(0.010)\end{array}$ & $\begin{array}{c}0.059 \\
(0.011)\end{array}$ & $\begin{array}{c}0.058 \\
(0.0052)\end{array}$ & $\begin{array}{c}0.050 \\
(0.0051)\end{array}$ \\
\hline $\begin{array}{l}\text { Spline in } \\
\text { years }\end{array}$ & & & & & & & & & & & & \\
\hline 1 to 8 & 0.063 & 0.031 & 0.024 & 0.020 & 0.0051 & 0.0023 & 0.063 & -0.032 & 0.028 & 0.017 & -0.0079 & -0.0072 \\
\hline years & $(0.0046)$ & $(0.013)$ & $(0.019)$ & $(0.019)$ & $(0.014)$ & $(0.012)$ & $(0.0068)$ & $(0.024)$ & $(0.043)$ & $(0.043)$ & $(0.029)$ & $(0.028)$ \\
\hline 9 to 12 & 0.091 & 0.064 & 0.051 & 0.049 & 0.047 & 0.040 & 0.105 & 0.097 & 0.067 & 0.043 & 0.050 & 0.049 \\
\hline years & $(0.0041)$ & $(0.0078)$ & $(0.011)$ & $(0.011)$ & $(0.0056)$ & $(0.0052)$ & $(0.0052)$ & $(0.012)$ & $(0.016)$ & $(0.017)$ & $(0.0097)$ & (0.0094) \\
\hline 13 plus & 0.091 & 0.081 & 0.073 & 0.064 & 0.085 & 0.064 & 0.128 & 0.086 & 0.086 & 0.101 & 0.071 & 0.057 \\
\hline years & $(0.0061)$ & $(0.0098)$ & $(0.014)$ & $(0.015)$ & $(0.0057)$ & $(0.0054)$ & $(0.0085)$ & $(0.013)$ & $(0.020)$ & $(0.021)$ & $(0.0078)$ & $(0.0076)$ \\
\hline $\begin{array}{l}\text { No. of ob- } \\
\text { servations }\end{array}$ & 7799 & 2064 & 938 & 800 & 3439 & 2934 & 3788 & 866 & 368 & 333 & 1181 & 1093 \\
\hline
\end{tabular}

Sources: Iowa 1915 Sample (see Goldin and Katz 1999b); 1940, 1950, and 1960 IPUMS.

Notes: Coefficients for "years of education" are from a regression of (log) annual earnings on all years of education. In the 1940, 1950, and 1960 censuses, years of education is given as "highest grade completed." In the 1915 Iowa State Census, years of education is the sum of common school, grammar school, high school, and college years (see Table 4, version I definition). Coefficients for the "spline in years" are also from a regression of (log) annual earnings. In 1940 and 1950 years in the various grades are inferred from "highest grade completed." In the 1915 Iowa State Census, years in each level are listed separately. "Full year" is defined for 1940, 1950, and 1960 as more than 49 weeks of work; in 1915 it is defined as listing no unemployment. Controls in all regressions are: quartic in potential experience, whether native born, and whether white. Potential experience in each sample is given by $\min ($ age -15 , age - years of education - 7). Each of the samples deletes the lowest 1 percent of earners. The samples for 1940, 1950, and 1960 include only those living in the state of Iowa. All regressions for 1915 are weighted by urban and rural sampling weights (see Goldin and Katz 1999b, Appendix for weighting information). Regressions for 1940 are weighted by the 1940 IPUMS sampling weights. Top-coded earnings in 1940 (\$\$5,000), $1950(\$ \$ 10,000)$, and 1960 (\$\$25,000) are multiplied by 1.5. Standard errors are in parentheses. 